\title{
ANALISIS PEMBENTUKAN CITRA PERUSAHAAN LISTRIK NEGARA MELALUI IMPLEMENTASI COMMUNITY RELATIONS
}

\section{Coprorate Image Analysis on The Implementation of Community Relations Programs by PLN}

\author{
Nurdini Prihastiti ${ }^{*}$ dan Yatri Indah Kusumastuti \\ Departemen Sains Komunikasi dan Pengembangan Masyarakat, Fakultas Ekologi Manusia, IPB \\ *) Email : nurdiniprihastiti@gmail.com
}

Diterima 3 Februari 2012 / Disetujui 2 April 2012

\begin{abstract}
A company will be able to survive if it has a good corporate image in the public. Public relations in every company is important to have the right strategies. To maintain coporate sustainibility, required relations between company with the community as an external public through community relations. PLN as a state company in charge of providing the power supply to all regions in Indonesia, run a community relations with the community in an area that has not received the power supply with Micro-hydro Power Plant (PLTMH) Programs. One of the PLTMH program is made in Lebak Picung. This study aims to determine the implementation of the community relations programs by PLN in Lebak Picung, as well as analyzing the relationship of community relations program with the process of corporate image building, and analyze the process of corporate image with PLN's corporate image formed on community that received PLTMH program in Lebak Picung. Data is collected by census at all household and the respondents are the head of family or member who can represent of all members in the house. Data obtained thorough observation, in depth interviews and interviews using a questionnaire. The overall question in the quesionnaire using an ordinal scale then continued on correlations test. The results show the influence of respondent in the brand image building process is the judgementto the benefits. Respondent's involvement in the program was not shown to have influence in corporate image process. In addition, there is a positive relationship between the process of corporate image that forms on the respondent. The more respondent rated PLTMH program provides positive benefits, the level of exposure, attentions and comprehensive of the responden are also tends to be high. Companies need to consider that the empowerment program should consider the needs of the targets, so the programs can be mutually beneficial. The company has a very positive image in the public so it maintain continuity of businessand community needs as program beneficiaries are met.
\end{abstract}

Kev words: communitv relations, corporate image. PLTMH

\section{PENDAHULUAN}

\section{Latar Belakang}

Relasi merupakan hal penting yang harus dijaga antara pihak-pihak yang saling berkepentingan. Iriantara (2004) mengungkapkan bahwa masing-masing pihak, baik yang berkepentingan sama maupun beda melakukan komunikasi untuk mencapai tujuan masing-masing maupun tujuan organisasi. Beragam hubungan dijalin oleh organisasi dan publik untuk mencapai tujuan organisasi dengan tidak mengabaikan tujuan publik. Bahkan bisa juga pencapaian tujuan bersama maupun tujuan yang sama yang hendak dicapai organisasi dan publikpubliknya.

Hubungan organisasi bisnis dan masyarakat tidak bisa dipandang dalam konteks relasi ekonomi saja, melainkan juga dalam bentuk relasi sosial. Prinsip ini merupakan pedoman sekaligus acuan bertindak bagi public relations perusahaan agar mampu menampilkan sekaligus mengkomunikasikan kedua bentuk relasi yang harus dimiliki organisasi bisnis. Berkaitan dengan hal tersebut public relations sebuah perusahaan harus menjaga agar hubungan antara organisasi dengan publiknya berlangsung baik.

Sebuah perusahaan akan dapat bertahan jika memiliki citra yang baik di mata publik. Publik akan memberikan dukungan, bantuan, serta kerjasama dengan perusahaan apabila perusahaan tersebut dapat dipercaya. Kepercayaan merupakan modal yang sangat penting untuk membangun kerjasama dengan publik eksternal. Berkaitan dengan hal ini, maka penting bagi public relations tiap perusahaan untuk memiliki strategi-strategi yang tepat. Salah satu yang bisa dilakukan adalah dengan menjalin relasi dengan masyarakat sebagai publik eksternal melalui kegiatan community relations sebagai hasil dari komunikasi dua arah antara perusahaan dan masyarakat, yang diharapkan dapat menghasilkan kesamaan kebutuhan antara kedua belah pihak.

PLN merupakan Perusahaan Listrik Negara yang bertugas menyediakan pasokan listrik, namun penyediaan listrik oleh pemerintah masih belum menjangkau di seluruh wilayah sampai ke desa-desa karena berbagai alasan dan berkendala. Pembangunan infrastruktur jaringan listrik untuk daerah-daerah yang terpencil memerlukan investasi yang besar. Sementara kebutuhan listrik di daerah yang 
padat penduduknya semakin meningkat sejalan dengan meningkatnya aktivitas ekonomi dan bertambahnya penduduk sehingga pemerintah juga harus menyediakan tambahan daya listrik untuk memenuhi kebutuhan tersebut. ${ }^{1}$ Mengatasi hal ini, salah satu cara yang dilakukan oleh PLN adalah dengan menjalankan community relations dengan masyarakat pada suatu wilayah yang belum mendapatkan aliran listrik dengan melakukan program Pembangkit Listrik Tenaga Mikrohidro (PLTMH). PLTMH dilakukan dengan cara community empowering bertujuan agar desa yang belum mendapatkan aliran listrik bisa memanfaatkan potensi yang ada di desanya untuk dijadikan sumber listrik, seperti memaksimalkan aliran sungai sebagai sumber listrik dengan adanya Pembangkit Listrik Tenaga Mikro Hidro (PLTMH).

Perusahaan dalam melakukan sebuah kegiatan tentu memperhatikan timbal balik yang didapatkan baik secara langsung maupun jangka panjang, salah satunya adalah citra perusahaan. Perusahaan dengan citra yang baik akan mendapatkan penerimaan untuk melakukan kegiatan usaha dari masyarakat. Masyarakat akan cenderung memiliki perhatian dan penerimaan terhadap sebuah perusahaan yang mampu menjawab kebutuhan dan memberikan dampak positif. Program yang sesuai dengan kebutuhan masyarakat dan sejalan dengan kepentingan perusahaan akan menghasilkan keuntungan positif pada kedua belah pihak. Berdasarkan latar belakang tersebut, peneliti tertarik untuk meneliti sejauhmana program community relations melalui program PLTMH efektif dilakukan sebagai salah satu upaya dalam membentuk citra perusahaan PLN pada sasaran program.

\section{Masalah}

Masalah penelitian dirumuskan sebagai berikut:

1) Bagaimana pelaksanaan community relations melalui program Pembangkit Listrik Mikro Hidro (PLTMH) di Lebak Picung?

2) Bagaimana hubungan pelaksanaan program PLTMH di Lebak Picung dengan proses pembentukan citra pada responden?

3) Sejauh mana hubungan proses pembentukan citra dengan citra perusahaan PLN yang terbentuk pada sasaran program PLTMH di Lebak Picung?

\section{Tujuan}

Tujuan penelitian dirumuskan sebagai berikut:

1) Menganalisis pelaksanaan community relations melalui program PLTMH di Lebak Picung

2) Menganalisis hubungan pelaksanaan community relations melalui program PLTMH di Lebak Picung dengan proses pembentukan citra pada sasaran program

\footnotetext{
${ }^{1}$ Tulisan Y. Aris Purwanto, Lilik B. Prasetya, Ellyn K. Damayanti, Rais Sonaji, yang disampaikan pada Kongres Perhimpunan Teknik Pertanian Indonesia, 8-9 Agustus 2009
}

3) Menganalisis hubungan proses pembentukan citra dengan citra perusahaan PLN pada sasaran program PLTMH di Lebak Picung

\section{Kegunaan}

Penelitian ini memiliki kegunaan sebagai berikut:

1) Bagi akademisi, penelitian ini diharapkan dapat menambah khasanah penelitian mengenai peran PR melalui kegiatan community relations sebagai upaya pembentukan citra perusahaan pada penerima program. Serta menjadi literatur bagi akademisi yang ingin mengkaji lebih jauh mengenai tanggung jawab sosial perusahaan melalui penerapan strategi community relations.

2) Public Relations Perusahaan, khususnya PLN, diharapkan tulisan ini dapat memberikan masukan yang bermanfaat dalam pelaksanaan comunity relations yang efektif dalam membentuk citra perusahaan. Sebagai bahan informasi dalam implikasi tugas, fungsi serta peranan Public Relations melalui penyelenggaraan community relations dalam pencapaian tujuan perusahaan tanpa mengabaikan kebutuhan masyarakat.

3) Bagi Masyarakat Sasaran Program Community Relations, penelitian ini diharapkan dapat membantu masyarakat untuk mengenali program community relations yang sesuai dengan kebutuhan mereka.

\section{PENDEKATAN TEORITIS}

\section{Tinjauan Pustaka}

\section{Community Relations}

Public relations mempunyai fungsi untuk menjalin komunikasi yang efektif antara perusahaan dengan publik internal maupun publik eksternal organisasi untuk mencapai tujuan organisasi. Fungsi Terdapat empat fungsi utama yang dituntut dari petugas PR menurut Ruslan (2008) dalam Novianti (2010) yaitu sebagi berikut: (1) Communicator yaitu sebagai juru bicara organisasi, PR berkomunikasi secara intensif melalui media dan kelompok masyarakat, (2) Relationship dengan membangun hubungan positif antara lembaga yang diwakilinya dengan publik internal maupun eksternal. Relationship juga berupaya menciptakan saling pengertian, kepercayaan, dukungan, kerjasama, dan toleransi antara kedua belah pihak. (3) Backup management yaitu melaksanakan dukungan manajemen atau menunjang kegiatan departemen lain dalam perusahaan demi terciptanya tujuan bersama dalam suatu kerangka tujuan pokok perusahaan, serta (5) Good image maker yaitu menciptakan citra perusahaan dan publisitas positif merupakan prestasi, reputasi, dan menjadi tujuan utama aktivitas PR dalam melaksanakan manajemen kehumasan membangun citra perusahaan. Diantara sekian fungsinya Ruslan (1998) menyebutkan adanya "fungsi community participation, yaitu partisipasi PR dalam melakukan suatu hubungan timbal balik dengan publik demi tercapai saling pengertian dan citra positif terhadap lembaga yang diwakili”. Selaras dengan fungsi PR 
tersebut, maka salah satu program yang diwujudkan adalah melalui pelaksanaan program Community Relations. Bentuk kegiatan ini merupakan salah satu dari beragam media komunikasi yang efektif untuk menyampaikan pesan komunikasi serta mendapat dukungan dari publik.

Iriantara (2007) mengungkapkan bahwa community relations bisa dipandang berdasarkan dua pendekatan. Pertama, dalam konsep PR lama yang memosisikan organisasi sebagai pemberi donasi, maka program community relations merupakan bagian dari aksi dan komunikasi dalam proses PR. Bila berdasarkan pengumpulan fakta dan perumusan masalah ditemukan bahwa permasalahan yang mendesak adalah tentang komunitas, maka dalam perencanaan akan disusun program community relations. Pendekatan kedua, memosisikan komunitas sebagai mitra, dan komunitas bukan sekedar kumpulan orang yang berdiam di sekitar wilayah operasi organisasi. Community relations merupakan program tersendiri yang merupakan wujud tangung jawab sosial organisasi. Dalam hal ini, organisasi bersama-sama dengan komunitas berusaha memecahkan permasalahan yang dihadapi komunitas. Organisasi dan komunitas bersama-sama memberikan sumber daya yang dimilikinya untuk memecahkan permasalahan dan mencapai tujuan bersama.

\section{Manfaat Community Relations}

Community relations ditujukan sebagai kegiatan berkomunikasi antar perusahaan dengan komunitas. Dalam hal ini Wilcox, Ault dan Agee dalam Iriantara (2007) mengungkapkan bahwa community relations merupakan dialog antar perusahaan dengan komunitas, dimana perusahaan sebenarnya dapat memantau bagaimana pendapat publik atau komunitas akan keberadaan perusahaan mereka. Isu apakah yang saat itu tengah berkembang di masyarakat yang kiranya nanti dapat berpengaruh pada eksistensi perusahaan.

\section{Tabel 1, Vlanfiaat Communinity Relations}

\begin{tabular}{|c|c|}
\hline Bagi Organisasi & Bagi Komumitas \\
\hline - Reputasi dan cita organimsasil lectih balk & 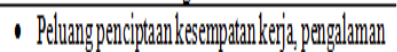 \\
\hline - "lisensis untulk beroperass' secara sosial & kerja dan pelathan \\
\hline - Memanfaatkan pengetaluanan dan tenagg kerja lokal & - Pendanaan investasi komunitas, pengembangan \\
\hline - Keamanan yang letili besar & infrastuthour \\
\hline 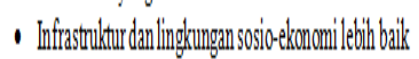 & - Keahlian komersial \\
\hline 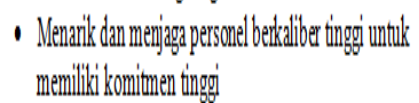 & 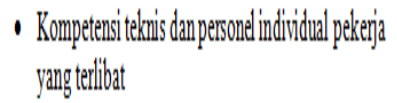 \\
\hline 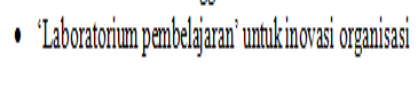 & 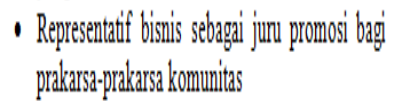 \\
\hline
\end{tabular}

Rogovsky (2005) dalam Iriantara (2007) menjelaskan adanya manfaat keterlibatan bagi komunitas dan organisasi bisnis pada pelaksanaan community relations melalui Tabel 1. Jika dulu banyak pandangan bahwa community relations adalah sebuah usaha yang hanya menguntungkan komunitas dan sia-sia bagi perusahaan karena hanya sekedar upaya penghambur-hamburan uang, namun sebenarnya pelaksanaan community relations yang dibangun berdasarkan tanggung jawab sosial korporat akan memberikan manfaat yang bisa dipetik oleh kedua belah pihak. Sehingga penting untuk disadari bahwa program-program community relations bukanlah program dari perusahaan untuk komunitas melainkan program untuk perusahaan dan komunitas.

\section{Citra Perusahaan}

Kotler (2000) mengungkapkan bahwa citra merupakan seperangkat keyakinan, ide, dan kesan yang dimiliki seseorang terhadap suatu obyek. Citra berkaitan erat dengan suatu penilaian, tanggapan, opini, kepercayaan publik, asosiasi atau simbol-simbol tertentu terhadap suatu perusahaan. Citra tersebut dapat bersifat positif atau negatif. Jefkins (1992) mengungkapkan beberapa jenis citra (image), yakni: citra bayangan (mirror image), citra yang berlaku (current image), citra yang diharapkan (wish image), citra majemuk (multiple image), serta citra perusahaan (corporate image). Penelitian ini memfokuskan pada citra perusahaan yaitu citra dari suatu organisasi secara keseluruhan, bukan citra atas produk maupun pelayanannya. Banyak hal yang menjadi dasar terbentuknya citra ini, diantaranya adalah sejarah atau riwayat perusahaan, keberhasilandi bidang keuangan yang pernah diraih, reputasi sebagai penyedia lapangan kerja dalam jumlah besar sampai kesediaan untuk turut memikul tanggung jawab sosial, ikut andil dalam terbentuknya citra positif perusahaan.

\section{Proses Terbentuknya Citra}

Terdapat tiga hal penting dalam citra, yaitu: kesan obyek, proses terbentuknya citra, dan sumber terpercaya. Obyek meliputi individu maupun perusahaan yang terdiri dari sekelompok orang di dalamnya. Citra dapat terbentuk dengan memproses informasi setiap waktu. Besarnya kepercayaan obyek terhadap sumber informasi memberikan dasar penerimaan atau penolakan informasi. Sumber informasi dapat berasal dari perusahaan secara langsung dan atau pihak-pihak lain secara langsung. Citra perusahaan menunjukkan kesan obyek terhadap perusahaan yang terbentuk dengan memproses informasi setiap waktu dari berbagai sumber informasi terpercaya.

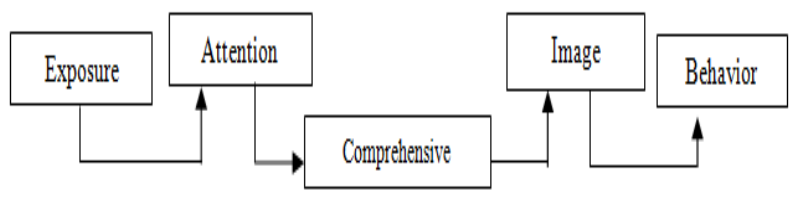

Sumber : Hawkins et all (2000)

\section{Gambar l. Proses Terbentuknya Citra Perusahaan}

Alma (2002) ${ }^{2}$ mengungkapkan bahwa "citra dibentuk berdasarkan impresi, berdasar pengalaman yang dialami seseorang terhadap sesuatu sebagai pertimbangan untuk mengambil keputusan". Proses terbentuknya citra perusahaan dapat diterangkan melalui Gambar 1.

\footnotetext{
${ }^{2}$ Dalam Iman Mulyana Dwi Suwandi, Citra Perusahaan Seri Manajemen Pemasaran, www.e-iman.uni.cc,
} 
Tahap-tahap dalam proses pembentukan persepsi atau citra tersebut secara rinci dijelaskan sebagai berikut: (a) Tahap Penangkapan Informasi (Exposure) yang terjadi disaat suatu rangsangan-rangsangan mencapai daerah syaraf penerima indera seseorang (Sensory Receptor), misalnya ketika seseorang mengetahui adanya kegiatan community relations yang dilakukan. Obyek mengetahui (melihat atau mendengar) upaya yang dilakukan perusahaan dalam membenuk citra perusahaan. (b) Tahap Perhatian (Attention), agar kegiatan yang dilakukan menjadi perhatian seseorang, maka setelah rangsangan mencapai daerah syaraf penerima maka selanjutnya rangsangan tersebut harus dapat menggertakkan saraf indera dan menimbulkan respon atau sensasi-sensasi pada otak (sensation). Contohnya ketika seseorang tertarik untuk mengetahui lebih jauh mengenai kegiatan community relations tersebut. Pada tahap ini, obyek memperhatikan upaya yang dilakukan perusahaan. (c) Tahap Pemahaman (Comprehensive), setelah adanya perhatian, obyek mencoba memahami semua yang ada pada upaya perusahaan. Misalnya dari pengetahuan mengenai kegiatan community relations yang dilakukan suatu perusahaan. Khalayak sasaran kemudian mulai memperhatikan dan mencoba untuk mengerti dan memberikan penilaian terhadap community relations tersebut. Hal tersebut kemudian mengarah pada pembentukan persepsi terhadap kegiatan yang dilakukan perusahaan yang bersangkutan.

\section{Elemen Citra Perusahaan}

Citra perusahaan merupakan persepsi masyarakat terhadap perusahaan yang dibentuk melalui proses komunikasi informasi baik yang disengaja maupun tidak disengaja, yang dilakukan maupun tidak dilakukan oleh perusahaan. Persepsi tersebut mungkin tidak selalu menggambarkan profil perusahaan yang sebenarnya. Apabila persepsi yang timbul positif maka dengan sendirinya akan mendukung aktivitas perusahaan, tetapi sebaliknya apabila persepsi yang timbul negatif maka akan menimbulkan akibat negatif pula terhadap perusahaan.

Perusahaan perlu mengirimkan pesan kepada lingkungan perusahaan baik internal amupun eksternal. Perusahaan harus sungguh-sungguh dalam usaha membentuk image yang positif, dalam hal ini penerimaan pesan merupakan faktor terpenting karena citra diukur dari penerima pesan. Pembentukan citra perusahaan diperlukan informasi yang lengkap. Menurut Harrison (1995), informasi yang lengkap mengenai citra perusahaan meliputi empat elemen, yaitu: (a) Personality, yaitu keseluruhan karakteristik perusahaan yang dipahami publik sasaran seperti perusahaan yang dipercaya, perusahaan yang mempunyai tanggung jawab sosial. Unsur dalam citra ini akan memberikan gambaran umum perusahaan secara keseluruhan, seperti perusahaan yang terpercaya, atau perusahaan yang bertanggungjawab sosial. (b) Reputation, merupakan hal yang telah dilakukan perusahaan dan diyakini publik sasaran berdasarkan pengalaman sendiri maupun pihak lain. Studi pustaka ini lebih menekankan keyakinan publik terhadap manfaat positif dari kegiatan community relations yang dilakukan perusahaan. (c) Value, merupakan nilai-nilai dan filosofi yang dimiliki suatu perusahaan, termasuk didalamnya kebijakan internal dan interaksi eksternal dengan pihak luar yang berhubungan dengan perusahaan. Serta (d) Corporate Identity yang merupakan komponen-komponen yang memudahkan pengenalan publik sasaran terhadap perusahaan.

\section{Kerangka Pemikiran}

PLN sebagai salah satu perusahaan yang menjalankan community relations harus memperhatikan faktor-faktor terkait pelaksanaan community relations melalui program PLTMH yang dilakukan di Lebak Picung. Pelaksanaan community relations harus memperhatikan keterlibatan masyarakat penerima program dalam perencanaan, pelaksanaan, dan pengelolaan PLTMH. Penilaian dilakukan untuk melihat kesesuaian hipotesis bahwa warga yang terlibat aktif dalam program akan memiliki citra yang lebih positif dibandingkan warga yang memiliki keterlibatan rendah. Adanya strategi community relations yang melibatkan peran penerima program akan mempengaruhi tingkat penangkapan informasi (exposure) mereka terhadap program maupun perusahaan. Penangkapan informasi oleh penerima program adalah sejauh mana penerima program menyadari adanya kegiatan community relations melalui program PLTMH. Keterlibatan dalam program juga mempengaruhi tingkat perhatian sasaran program. Penilaian sasaran program terhadap manfaat program juga menjadi hal yang perlu diperhatikan dalam pelaksanaan community relations. Adanya manfaat program yang sesuai dengan kebutuhan masyarakat juga berpengaruh pada pemahaman penerima program. Pemahaman masyarakat terhadap program adalah sejauh mana pengetahuan penerima program tentang implementasi community relations, semakin tinggi kesesuaian manfaat yang didapatkan penerima program akan meningkatkan tingkat pemahaman (comprehensive) penerima program.

Adanya kesesuaian proses pembentukan citra perusahaan akan mempengaruhi citra perusahaan yang terbentuk. Citra perusahaan dinilai dari personality, reputation, value ethics, serta corporate identity menurut sasaran program terhadap perusahaan. Proses pembentukan citra yang baik akan cenderung meningkatkan citra perusahaan yang terbangun. 


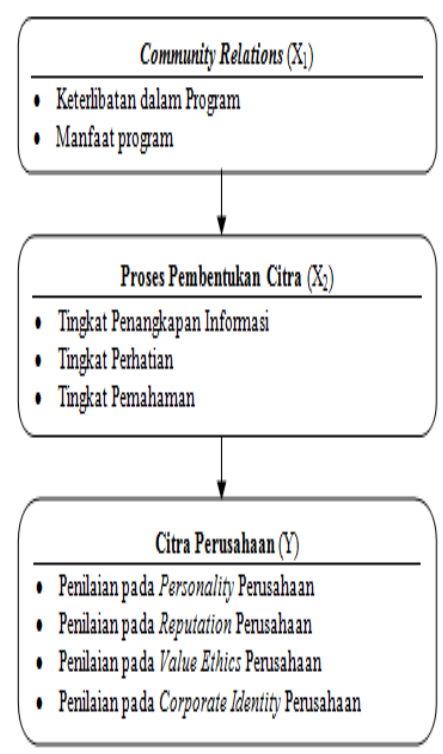

Gambar2. Kerangka Pemilkiran Pembentukan Citra Perusahaan Melalui Implementasi Community Relations.

\section{Hipotesis}

1. Terdapat hubungan positif antara pelaksanaan community relations melalui program community empowering PLTMH di Lebak Picung dengan pembentukan citra perusahaan.

- Terdapat hubungan positif antara keterlibatan aktif dalam program dengan tingkat penangkapan informasi (exposure) pada sasaran program

- Terdapat hubungan positif antara keterlibatan aktif dalam program dengan tingkat perhatian (attention) sasaran program

- Terdapat hubungan positif antara kesesuaian manfaat program community relations Desa Mandiri Energi di Lebak Picung dengan tingkat pemahaman (comprehensive) pada sasaran program program

2. Terdapat hubungan positif antara proses pembentukan citra perusahaan melalui pelaksanaan community relations program PLTMH di Lebak Picung dengan citra perusahaan yang terbangun pada penerima program community relations.

\section{PENDEKATAN LAPANGAN}

Penelitian ini dilakukan di salah lokasi penerima program PLTMH sebagai bentuk community relations PLN yaitu di Lebak Picung, Desa Hegarmanah, Kecamatan Cibeber, Kabupaten Lebak, Provinsi Banten. Penelitian dilakukan dari Bulan Juni 2011 hingga Januari 2012. ${ }^{3}$ Penelitian yang dilakukan adalah penelitian pengujian hipotesis atau penelitian penjelasan (explanatory research). Penelitian explanatory merupakan penelitian dengan menjelaskan hubungan antara variabel-variabel penelitian dan menguji

\footnotetext{
${ }^{3}$ Mulai dari penyusunan proposal skripsi, kolokium, perbaikan proposal, perijinan, pengambilan data, pengolahan data, hingga sidang skripsi dan perbaikan skripsi.
}

hipotesa yang telah dirumuskan sebelumnya (Singarimbun dan Effendi, 1989).

Penggalian data kuantitatif dilakukan dengan wawancara menggunakan kuesioner kepada responden. Pengambilan data dilakukan dengan cara sensus pada seluruh rumah tangga sehingga responden dalam penelitian ini merupakan seluruh kepala keluarga atau anggota keluarga yang dapat mewakili penilaian seluruh anggota dalam rumahnya. Sensus dilakukan untuk mendapat secara keseluruhan citra PLN pada seluruh rumah tangga yang mendapat aliran listrik PLTMH. Pendekatan kualitatif dilakukan dengan wawancara mendalam dengan informan dan responden. Pemilihan informan dilakukan secara purposive, informan kunci yang dipilih adalah divisi Public Relations PLN, PPLH IPB sebagai pelaksana program PLTMH di Lebak Picung dan warga yang dihormati di Lebak Picung. Analisis data kualitatif digunakan untuk mempertajam hasil penelitian. Selain data primer tersebut juga dilengkapi dengan data sekunder yang diperoleh dari dokumen-dokumen yang terkait dengan data-data bentuk kegiatan community relations PLN dari studi literatur yang berkaitan dengan tujuan penelitian seperti buku, artikel, skripsi, tesis, dan karya ilmiah, serta data terkait pelaksanaan community relations PT PLN di Lebak Picung yang telah terpublikasi

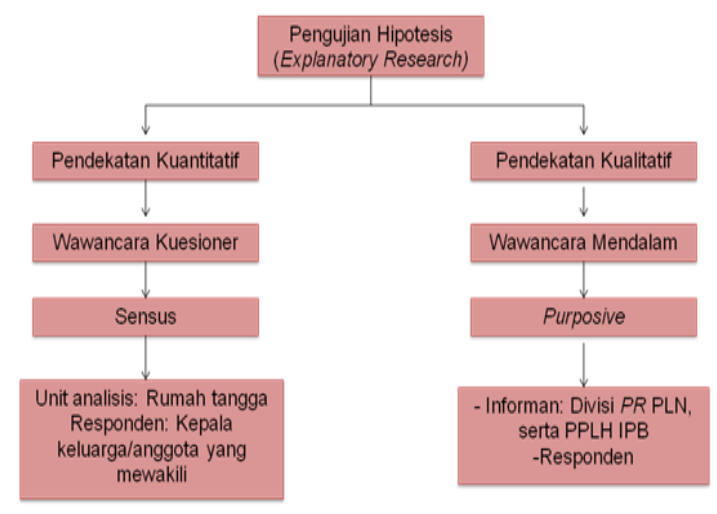

Gambar 3. Metodologi Penelitian dan Teknik Pengumpulan Data

Pertanyaan dalam kuesioner ditujukan untuk mendapatkan data tentang penilaian responden terhadap perusahaan sehingga skala pengukuran yang digunakan merupakan skala likert dengan data ordinal. Data kuantitatif yang didapatkan dari kuesioner sebelumnya telah dilakukan pengkodean data. Sistem skoring dibuat konsisten, jadi semakin tinggi skor maka akan semakin tinggi kategorinya. Data kemudian dikategorikan dengan menggunakan teknik scoring normatif yang dikategorikan berdasarkan interval kelas. Data yang didapatkan disusun berdasarkan tabel frekuensi tiap variabel, kemudian dilakukan tabulasi silang antara variabel yang diuji, dan uji korelasi dengan menggunakan software SPSS for Windows Versi 16.0. Analisis korelasi secara statistik dengan uji statistik Spearman Rank Order Correlation digunakan untuk mengetahui hubungan antar variabel, yaitu hubungan pelaksanaan program dengan proses pembentukan citra, keterlibatan responden dalam program dengan tingkat penangkapan informasi dan tingkat perhatian, manfaat program dengan tingkat penerimaan, serta proses pembentukan citra perusahaan dengan citra perusahaan yang terbentuk. 
Analisis korelasi bivariate digunakan untuk mencari derajat keeratan hubungan antarvariabel, semakin tinggi nilai korelasi, semakin tinggi nilai keeratan hubungan kedua variabel. Nilai korelasi memiliki rentang antara 0 sampai 1 atau 0 sampai -1. Tanda positif dan negatif menunjukkan arah hubungan. Tanda positif menunjukkan arah hubungan searah, yaitu jika satu variabel naik, variabel yang lain naik. Tanda negatif menunjukkan hubungan yang berlawanan, jika satu variabel naik maka variabel yang lainnya turun. (Trihendradi, 2010)

Berdasarkan Korelasi Rank Spearman, hubungan antar variabel yang diteliti dilihat dari signifikansi/probabilitas/ $\alpha$. Signifikansi yang digunakan pada penelitian ini adalah sebesar $\alpha(0,1)$ yang artinya hasil penelitian mempunyai kesempatan untuk benar atau tingkat kepercayaan 90 persen dan tingkat kesalahan 10 persen. Dasar pengambilan keputusan adalah (a) Jika angka signifikansi hasil penelitian $<0,1$ maka $\mathrm{H} 0$ ditolak. Jadi hubungan kedua variabel signifikan, dan (b) Jika angka signifikansi hasil penelitian $>0,1$ maka $\mathrm{H} 0$ diterima. Jadi hubungan antar variabel tidak signifikan.

\section{PROFIL PLTMH LEBAK PICUNG}

\section{Coorporate Social Responsibility (CSR) PLN}

Program pemberdayaan yang dilakukan oleh PLN sesuai dengan UU 40 tahun 2007 tentang PT (Pasal 74) dilakukan dengan kegiatan CSR. CSR PLN mengalami sejarah panjang, diawali pada tahun 1991 setelah diterbitkannya Keputusan Pemerintah tahun 1989 mengenai pelaksanaan pemberdayaan usaha kecil dan koperasi, kegiatan ini bernama Program Pembinaan Pengusaha Ekonomi Lemah dan Koperasi (PPELK). Sejak tahun tahun 1994 program PPELK itu berganti menjadi Pembinaan Usaha Kecil dan Koperasi (PUKK) dengan memberikan modal kerja dan bantuan pelatihan serta membantu pemasaran dengan status hibah. Tahun 2007, terbit Peraturan Menteri Negara BUMN No. PER05/MBU/2007 khususnya yang tercantum pada Pasal 8 yang menyatakan bahwa setiap BUMN wajib menyisihkan keuntungan untuk program kemitraan dan program bina lingkungan (community development). Sejak saat itu, program PUKK pun berganti nama menjadi Program Kemitraan dan Bina Lingkungan (PKBL) yang merupakan program Partisipasi Pemberdayaan Lingkungan (P3L) yang senafas dengan CSR.

Kepedulian PLN terhadap mitra binaan/masyarakat adalah kewajiban dari Kementrian BUMN. Kewajiban utamanya adalah memenuhi penyediaan tenaga listrik di area Indonesia. Dana program kemitraan dialokasikan sebesar 2 persen dari laba perusahaan setelah pajak. PLN sendiri memiliki divisi khusus untuk menangani kegiatan CSR perusahaan.

Pelaksanaan kegiatan CSR PLN dilakukan untuk mencapai terwujudnya keharmonisan hubungan antara PLN dengan masyarakat sehingga akan menunjang keberhasilan kegiatan perusahaan dalam menyediakan tenaga listrik bagi masyarakat. Sejalan dengan visi ini dilakukan dengan membantu pengembangan kemampuan masyarakat agar dapat berperan dalam pembangunan; berperan aktif dalam meningkatkan kualitas hidup masyarakat yang dilakukan dengan cara community empowering; berperan aktif dalam mencerdaskan masyarakat melalui pendidikan; berperan aktif dalam mendorong tersedianya tenaga listrik untuk meningkatkan kualitas hidup dengan jalan penggunaan listrik pada siang hari untuk Industri Rumah Tangga dan pengembangan desa mandiri energi; berperan aktif dalam menjaga kesinambungan lingkungan melalui pelestarian alam.

\section{Community Relations PLN}

PLN melihat Community Relation sebagai kegiatan kegiatan yang menyangkut pengembangan kesepahaman melalui komunikasi dan informasi kepada para pihak yang terkait (stakeholder). Misalnya: pengembangan kesepahaman melalui komunikasi dan informasi kepada para pihak yang terkait, untuk peningkatan hubungan baik dengan kelompok masyarakat dan pemerintah setempat; bantuan konsultasi publik; serta bantuan penyuluhan.

Bentuk nyata community relations dilakukan juga melalui program Pembangkit Listrik Tenaga Mikrohidro (PLTMH). Pengadaan listrik tidak terlepas dari sumber daya yang dimiliki. PLN dengan sejumlah pembangkit listriknya mampu menyinari hampir seluruh kawasan nusantara. Tenaga alternatif yang tersedia bisa menjadi solusi untuk mendapatkan tenaga listrik di daerah yang belum terjangkau oleh listrik. Selain itu, pasokan tenaga listrik memakai energi yang tidak dapat diperbaharui seperti Bahan Bakar Minyak (BBM) dan Batu Bara yang mengalami lonjakan harga bisa membuat PLN defisit, bahkan krisis listrik. Berkaitan dengan latar belakang tersebut, maka pemberdayaan masyarakat untuk menciptakan energi alternatif sangat diperlukan untuk memenuhi kuota listrik dan penghematan sumber daya, yaitu melalui program biogas, bio metan, serta PLTS, dan PLTMH.

PLTMH dilakukan dengan cara community empowering yaitu melibatkan masyarakat mulai dari perencanaan hingga pengelolaan. Tujuan pelibatan masyarakat secara langsung dalam pelaksanaan PLTMH adalah untuk meningkatkan rasa kepemilikan terhadap PLTMH sehingga masyarakat bisa mandiri dalam mengelola dan menjaganya.

Lokasi PLTMH bantuan CSR PLN di Gunung Halimun Salak Banten terdapat di delapan lokasi, yaitu di Desa Adat Susunan Karang Asem dengan kapasitas $25 \mathrm{~kW}$, Dusun Kampung Sawah dengan kapasitas $6 \mathrm{~kW}$ yang menerangi $40 \mathrm{KK}$, Dusun Bojong Cisono dengan kapasitas $6 \mathrm{~kW}$ yang mampu menerangi $70 \mathrm{KK}$, Dusun Cibadak dengan kapasitas $6 \mathrm{~kW}$ yang menerangi $266 \mathrm{KK}$, Dusun Cisuren dengan kapasitas 2x6 kW menerangi 120 KK, Dusun Ciawi dengan kapasitas $6 \mathrm{~kW}$ untuk menerangi $180 \mathrm{KK}$, Dusun Leuwi Gajah dengan kapasitas 2x6 kW mampu menerangi $70 \mathrm{KK}$, dan Dusun Lebak Picung dengan kapasitas $10 \mathrm{~kW}$ mampu menerangi 52 KK. Penelitian ini memfokuskan pada PLTMH yang terdapat di Dusun Lebak Picung.

\section{Program Pembangkit Listrik Tenaga Mikro Hidro (PLTMH) Lebak Picung}


Pelaksanaan kegiatan CSR perusahaan melalui program PLTMH di Lebak Picung dilakukan PLN dengan bermitra dengan pihak lain. Organisasi pelaksana program PLTMH dan program pendukung dalam rangka menyelenggarakan CSR PLN di Lebak Picung adalah Pusat Penelitian Lingkungan Hidup (PPLH) IPB. Tim pelaksana kegiatan terdiri dari penanggung jawab yang dipimpin secara langsung oleh ketua PPLH-IPB, dengan bagian Pengembangan Energi Terbarukan, Pengelolaan DAS dan Sumberdaya Lahan, Kelembagaan dan Sosial Ekonomi Kehutanan, 2 asisten tenaga ahli, 2 pendamping masyarakat, serta pegawai administrasi. Program ini sepenuhnya dilakukan oleh PPLH dengan pendanaan dari PLN. Tahapan pelaksanaan program diawali dengan survey lokasi pada daerah dengan potensi sungai dan belum mendapatkan listrik, dan Lebak Picung merupakan daerah yang belum mendapatkan aliran listrik dari PLN dan memiliki potensi untuk dikembangkan PLTMH. Survey lokasi dan pendekatan dengan warga dimulai dari akhir tahun 2008. Pelaksanaan kegiatan CSR PLN dengan program PLTMH dimulai dengan melakukan identifikasi lokasi dan kelembagaan yang ada di daerah tersebut, dilanjutkan dengan survey teknis terkait perencanaan PLTMH, dalam masa survey dilakukan juga pendampingan.

Selama masa perencanaan pembangunan PLTMH juga dilakukan pembentukan kelembagaan yang diperlukan terutama terkait pengelolaan PLTMH. Kelembagaan menjadi aspek penting untuk menunmbuhkan kepedulian dan kemandirian dari masyarakat untuk mengelola PLTMH, sehingga ketika tidak lagi dilakukan pendampingan masyarakat bisa secara mandiri mengelola PLTMH. Pembangunan PLTMH dilakukan dengan melibatkan masyarakat. Masyarakat kemudian juga diberikan pelatihan penggunaan dan perawatan PLTMH. Sumber energi yang dihasilkan PLTMH sangat bergantung dengan persediaan debit air yang tentunya juga tergantung dengan kondisi hutan di sekitar Lebak Picung. Berkaitan dengan hal tersebut PLN melalui PPLH juga melakukan pelatihan rehabilitasi hutan dan lahan, pengumpulan bibit dari dalam hutan, pembibitan, serta penanaman. Pengembangan ekonomi produktif juga dilakukan agar masyarakat dapat memanfaatkan listrik pada siang hari untuk membantu pemasukan rumah tangga. Melalui identifikasi potensi di Lebak Picung, sumber energi listrik dari PLMTH bisa digunakan untuk proses pembuatan gula semut yang merupakan proses lebih lanjut dari pengolahan gula aren, sehingga mampu meningkatkan nilai tambah bagi masyarakat. Program pendukung PLTMH yaitu pengembangan ekonomi produktif dan rehabilitasi hutan dan lahan dijalankan sampai proyek kerjasama antara PPLH dan PLN selesai, namun sayangnya pengembangan ekonomi produktif melalui pembuatan gula tidak dilakukan lagi oleh masyarakat. Tidak adanya pendampingan membuat program lain yang ditujukan agar masyarakat mampu meningkatkan ekonomi keluarga dengan memanfaatkan listrik PLTMH pada siang hari ternyata tidak berkelanjutan. Kelembagaan yang ditujukan untuk mengelola penggunaan dan perawatan PLTMH berlangsung secara kontinu. Masyarakat memiliki jadwal jaga rutin tiap malam dan terdapat sistem pembayaran tiap bulan untuk uang kas yang ditujukan untuk perawatan peralatan PLTMH.

Setelah melewati masa perencanaan, pembangunan, running-test, serta pendampingan selama tahun 2009, PLTMH resmi menjadi pembangkit listrik bagi masyarakat Lebak Picung pada tahun 2010 hingga saat ini. Selama tahun 2010, PLTMH mengalami kematian selama 4 bulan karena debit air sungai Ciambulaung yang sedikit saat musim hujan. Pendampingan pada masyarakat telah berakhir sesuai dengan kerjasama yang dilakukan pendamping dan pelaksana program yaitu PPLH IPB dengan pihak perusahaan yaitu PLN. Sayangnya pendampingan ini sudah tidak dijalankan saat masyarakat belum sepenuhnya mandiri. Terdapat informasi yang belum dimiliki sasaran program seperti teknis penggantian alat oleh PLN jika terjadi kerusakan pada PLTMH.

Program pemberdayaan yang dilakukan dengan bekerjasama dengan mitra memang memberikan manfaat bagi perusahaan, yaitu program dijalankan dengan melibatkan ahli-ahli dalam bidangnya. Namun sayangnya komunikasi yang dilakukan oleh mitra sebagai tangan kanan perusahaan justru membuat sasaran program lebih mengenal organisasi mitra pelaksana dibanding PLN. Tidak adanya komunikasi secara langsung yang dilakukan PR PLN juga membuat informasi tentang perusahaan tidak sepenuhnya dimiliki sasaran program.

\section{Kondisi Geografis}

Kampung Lebak Picung berada dalam wilayah Desa Cibeber yang saat ini berubah menjadi Desa Hegarmanah, Kecamatan Cibeber, Kabupaten Lebak. Labakpicung secara administratif masuk ke RW 04 Desa Hegarmanah dengan luas wilayah 230,98 ha, dan hanya 6,41 persen atau 14,81 ha saja yang didirikan bangunan. Sebagian besar wilayah Lebak Picung di dominasi oleh hutan dan kebun campuran. Handini (2010) juga mengungkapkan bahwa 70,48 persen wilayah Lebak Picung atau sekitar 162,8 ha wilayah kampung berada di kawasan TNGHS. Adapun batas-batas kampung yaitu, bagian utara berbatasan dengan Desa Ciusul, bagian barat berbatasan dengan kampung Karangropong dan Taman Nasional Gunung Halimun Salak, dan bagian selatan serta timur berbatasan dengan TNGHS yang dibatasi oleh sungai Ciambulaung.

Kampung Lebak Picung terletak di lembah yang dapat di akses melalui jalan berbatu dengan lebar 1,5 - $2 \mathrm{~m}$ diantara jurang dan tebing. Akses jalan menuju Lebak Picung dapat dilalui dengan kendaraan sepeda motor atau berjalan kaki. Perjalanan dari kampung terdekat (Kampung Hegarmanah) ke Kampung Lebak Picung adalah sekitar 20 menit dengan sepeda motor atau 1 jam dengan berjalan kaki. Hal ini dikarenakan kondisi jalan yang masih terbuat dari bebatuan dengan kemiringannya cukup terjal.

Rumah penduduk didirikan dipinggir-pinggir Sungai Ciambulaung di sekitar perbukitan yang mengitari lembah. Adanya potensi sungai di Lebak Picung dan sebagian besar wilayahnya masih di dominasi dengan hutan dan pepohonan membuat daerah ini menjadi daerah yang memiliki potensi untuk dikembangkan PLTMH. 


\section{Kondisi Sosial}

Masyarakat yang berada di Kecamatan Cibeber sebagian besar merupakan suku Sunda dan beberapa juga terdapat masyarakat pendatang dari luar suku Sunda. Sebagian besar masyarakat di Dusun Lebak Picung digolongkan kedalam masyarakat kasepuhan. Adapun masyarakat yang tidak digolongkan ke dalam kasepuhan adalah masyarakat pendatang yang menikah dengan orang Lebak Picung. Secara formal, ketua RW memegang peranan tertinggi di Lebak Picung, namun ada juga kelembagaan yang dimiliki masyarakat kasepuhan di Lebak Picung. Pada masyarakat Lebak Picung, kelembagaan kasepuhan memiliki peranan yang lebih dibandingkan kelembagaan formal.

Jumlah penduduk di Lebak Picung berdasarkan data RW setempat pada tahun 1989 adalah 120 orang, tahun 1997 meningkat menjadi 153 orang, dan pada tahun 2007 adalah sebanyak 180 orang, pada saat penelitian dilakukan pendataan terhadap jumlah tiap anggota rumah tangga pada seluruh rumah didapatkan hasil penduduk Lebak Picung adalah sebanyak 180 orang. Diperkirakan jumlah penduduk akan mengalami peningkatan di masa yang akan datang. Hal ini disebabkan oleh adanya sistem sosial yang terbuka, dimana masyarakat bisa keluar masuk dan menetap di kampung ini. Selain itu, adanya tradisi di masyarakat untuk menikah muda, bisa menjadi penyebab dalam peningkatan jumlah penduduk. Pertambahan jumlah penduduk ini menjadi salah satu alasan pentingnya pengadaan listrik untuk mendukung kehidupan dan membantu dalam pencapaian kesejahteraan mereka.

Masyarakat Lebak Picung memiliki hubungan yang erat satu sama lain. Hal ini bisa menjadi potensi untuk dikembangkannya sebuah kelembagaan yang ditujukan untuk mengatur operasionalisasi program pemberdayaan. Ini bisa menjadi modal sosial dengan adanya serangkaian nilai-nilai atau norma-norma informal yang dimiliki bersama diantara para anggota suatu kelompok yang memungkinkan terjalinnya kerjasama diantara mereka. Adanya modal sosial ini memudahkan keberhasilan program pemberdayaan diterapkan dan keberhasilan bagi masyarakat dalam mendapatkan kesejahteraan dari kerjasama yang mereka lakukan

\section{Karakteristik Responden}

Berdasarkan Tabel 2 diketahui bahwa dari 52 responden, 35 responden (67 persen) berjenis kelamin laki-laki dan tujuh belas responden (33 persen) lainnya berjenis kelamin perempuan. Dua rumah tangga diwakili oleh perempuan (istri), karena suaminya usianya sudah di atas 80 tahun dan dalam keadaan tidak sehat, sedangkan perempuan yang lain mewakili suaminya yang sedang bekerja.

Pertanyaan dalam kuesioner ditujukan untuk mendapatkan data tentang penilaian responden terhadap perusahaan sehingga skala pengukuran yang digunakan merupakan skala likert dengan data ordinal. Data kuantitatif yang didapatkan dari kuesioner sebelumnya telah dilakukan pengkodean data. Sistem skoring dibuat konsisten, jadi semakin tinggi skor maka akan semakin tinggi kategorinya. Data kemudian dikategorikan dengan menggunakan teknik scoring normatif yang dikategorikan berdasarkan interval kelas. Data yang didapatkan disusun berdasarkan tabel frekuensi tiap variabel, kemudian dilakukan tabulasi silang antara variabel yang diuji, dan uji korelasi dengan menggunakan software SPSS for Windows Versi 16.0. Analisis korelasi secara statistik dengan uji statistik Spearman Rank Order Correlation digunakan untuk mengetahui hubungan antar variabel, yaitu hubungan pelaksanaan program dengan proses pembentukan citra, keterlibatan responden dalam program dengan tingkat penangkapan informasi dan tingkat perhatian, manfaat program dengan tingkat penerimaan, serta proses pembentukan citra perusahaan dengan citra perusahaan yang terbentuk.

Analisis korelasi bivariate digunakan untuk mencari derajat keeratan hubungan antarvariabel, semakin tinggi nilai korelasi, semakin tinggi nilai keeratan hubungan kedua variabel. Nilai korelasi memiliki rentang antara 0 sampai 1 atau 0 sampai -1 . Tanda positif dan negatif menunjukkan arah hubungan. Tanda positif menunjukkan arah hubungan searah, yaitu jika satu variabel naik, variabel yang lain naik. Tanda negatif menunjukkan hubungan yang berlawanan, jika satu variabel naik maka variabel yang lainnya turun. (Trihendradi, 2010)

Berdasarkan Korelasi Rank Spearman, hubungan antar variabel yang diteliti dilihat dari signifikansi/probabilitas/ $\alpha$. Signifikansi yang digunakan pada penelitian ini adalah sebesar $\alpha(0,1)$ yang artinya hasil penelitian mempunyai kesempatan untuk benar atau tingkat kepercayaan 90 persen dan tingkat kesalahan 10 persen. Dasar pengambilan keputusan adalah (a) Jika angka signifikansi hasil penelitian $<0,1$ maka $\mathrm{H} 0$ ditolak. Jadi hubungan kedua variabel signifikan, dan (b) Jika angka signifikansi hasil penelitian $>0,1$ maka $\mathrm{H} 0$ diterima. Jadi hubungan antar variabel tidak signifikan.

\section{PROFIL PLTMH LEBAK PICUNG}

\section{Coorporate Social Responsibility (CSR) PLN}

Program pemberdayaan yang dilakukan oleh PLN sesuai dengan UU 40 tahun 2007 tentang PT (Pasal 74) dilakukan dengan kegiatan CSR. CSR PLN mengalami sejarah panjang, diawali pada tahun 1991 setelah diterbitkannya Keputusan Pemerintah tahun 1989 mengenai pelaksanaan pemberdayaan usaha kecil dan koperasi, kegiatan ini bernama Program Pembinaan Pengusaha Ekonomi Lemah dan Koperasi (PPELK). Sejak tahun tahun 1994 program PPELK itu berganti menjadi Pembinaan Usaha Kecil dan Koperasi (PUKK) dengan memberikan modal kerja dan bantuan pelatihan serta membantu pemasaran dengan status hibah. Tahun 2007, terbit Peraturan Menteri Negara BUMN No. PER05/MBU/2007 khususnya yang tercantum pada Pasal 8 yang menyatakan bahwa setiap BUMN wajib menyisihkan keuntungan untuk program kemitraan dan program bina lingkungan (community development). Sejak saat itu, program PUKK pun berganti nama menjadi Program Kemitraan dan Bina Lingkungan (PKBL) yang merupakan program Partisipasi Pemberdayaan Lingkungan (P3L) yang senafas dengan CSR.

Kepedulian PLN terhadap mitra binaan/masyarakat adalah kewajiban dari Kementrian BUMN. Kewajiban 
utamanya adalah memenuhi penyediaan tenaga listrik di area Indonesia. Dana program kemitraan dialokasikan sebesar 2 persen dari laba perusahaan setelah pajak. PLN sendiri memiliki divisi khusus untuk menangani kegiatan CSR perusahaan.

Pelaksanaan kegiatan CSR PLN dilakukan untuk mencapai terwujudnya keharmonisan hubungan antara PLN dengan masyarakat sehingga akan menunjang keberhasilan kegiatan perusahaan dalam menyediakan tenaga listrik bagi masyarakat. Sejalan dengan visi ini dilakukan dengan membantu pengembangan kemampuan masyarakat agar dapat berperan dalam pembangunan; berperan aktif dalam meningkatkan kualitas hidup masyarakat yang dilakukan dengan cara community empowering; berperan aktif dalam mencerdaskan masyarakat melalui pendidikan; berperan aktif dalam mendorong tersedianya tenaga listrik untuk meningkatkan kualitas hidup dengan jalan penggunaan listrik pada siang hari untuk Industri Rumah Tangga dan pengembangan desa mandiri energi; berperan aktif dalam menjaga kesinambungan lingkungan melalui pelestarian alam.

\section{Community Relations PLN}

PLN melihat Community Relation sebagai kegiatan kegiatan yang menyangkut pengembangan kesepahaman melalui komunikasi dan informasi kepada para pihak yang terkait (stakeholder). Misalnya: pengembangan kesepahaman melalui komunikasi dan informasi kepada para pihak yang terkait, untuk peningkatan hubungan baik dengan kelompok masyarakat dan pemerintah setempat; bantuan konsultasi publik; serta bantuan penyuluhan.

Bentuk nyata community relations dilakukan juga melalui program Pembangkit Listrik Tenaga Mikrohidro (PLTMH). Pengadaan listrik tidak terlepas dari sumber daya yang dimiliki. PLN dengan sejumlah pembangkit listriknya mampu menyinari hampir seluruh kawasan nusantara. Tenaga alternatif yang tersedia bisa menjadi solusi untuk mendapatkan tenaga listrik di daerah yang belum terjangkau oleh listrik. Selain itu, pasokan tenaga listrik memakai energi yang tidak dapat diperbaharui seperti Bahan Bakar Minyak (BBM) dan Batu Bara yang mengalami lonjakan harga bisa membuat PLN defisit, bahkan krisis listrik. Berkaitan dengan latar belakang tersebut, maka pemberdayaan masyarakat untuk menciptakan energi alternatif sangat diperlukan untuk memenuhi kuota listrik dan penghematan sumber daya, yaitu melalui program biogas, bio metan, serta PLTS, dan PLTMH.

PLTMH dilakukan dengan cara community empowering yaitu melibatkan masyarakat mulai dari perencanaan hingga pengelolaan. Tujuan pelibatan masyarakat secara langsung dalam pelaksanaan PLTMH adalah untuk meningkatkan rasa kepemilikan terhadap PLTMH sehingga masyarakat bisa mandiri dalam mengelola dan menjaganya.

Lokasi PLTMH bantuan CSR PLN di Gunung Halimun Salak Banten terdapat di delapan lokasi, yaitu di Desa Adat Susunan Karang Asem dengan kapasitas $25 \mathrm{~kW}$, Dusun Kampung Sawah dengan kapasitas $6 \mathrm{~kW}$ yang menerangi $40 \mathrm{KK}$, Dusun Bojong Cisono dengan kapasitas $6 \mathrm{~kW}$ yang mampu menerangi $70 \mathrm{KK}$, Dusun Cibadak dengan kapasitas $6 \mathrm{~kW}$ yang menerangi $266 \mathrm{KK}$, Dusun Cisuren dengan kapasitas 2x6 kW menerangi 120 $\mathrm{KK}$, Dusun Ciawi dengan kapasitas $6 \mathrm{~kW}$ untuk menerangi $180 \mathrm{KK}$, Dusun Leuwi Gajah dengan kapasitas 2x6 kW mampu menerangi $70 \mathrm{KK}$, dan Dusun Lebak Picung dengan kapasitas $10 \mathrm{~kW}$ mampu menerangi 52 KK. Penelitian ini memfokuskan pada PLTMH yang terdapat di Dusun Lebak Picung.

\section{Program Pembangkit Listrik Tenaga Mikro Hidro (PLTMH) Lebak Picung}

Pelaksanaan kegiatan CSR perusahaan melalui program PLTMH di Lebak Picung dilakukan PLN dengan bermitra dengan pihak lain. Organisasi pelaksana program PLTMH dan program pendukung dalam rangka menyelenggarakan CSR PLN di Lebak Picung adalah Pusat Penelitian Lingkungan Hidup (PPLH) IPB. Tim pelaksana kegiatan terdiri dari penanggung jawab yang dipimpin secara langsung oleh ketua PPLH-IPB, dengan bagian Pengembangan Energi Terbarukan, Pengelolaan DAS dan Sumberdaya Lahan, Kelembagaan dan Sosial Ekonomi Kehutanan, 2 asisten tenaga ahli, 2 pendamping masyarakat, serta pegawai administrasi. Program ini sepenuhnya dilakukan oleh PPLH dengan pendanaan dari PLN. Tahapan pelaksanaan program diawali dengan survey lokasi pada daerah dengan potensi sungai dan belum mendapatkan listrik, dan Lebak Picung merupakan daerah yang belum mendapatkan aliran listrik dari PLN dan memiliki potensi untuk dikembangkan PLTMH. Survey lokasi dan pendekatan dengan warga dimulai dari akhir tahun 2008. Pelaksanaan kegiatan CSR PLN dengan program PLTMH dimulai dengan melakukan identifikasi lokasi dan kelembagaan yang ada di daerah tersebut, dilanjutkan dengan survey teknis terkait perencanaan PLTMH, dalam masa survey dilakukan juga pendampingan.

Selama masa perencanaan pembangunan PLTMH juga dilakukan pembentukan kelembagaan yang diperlukan terutama terkait pengelolaan PLTMH. Kelembagaan menjadi aspek penting untuk menunmbuhkan kepedulian dan kemandirian dari masyarakat untuk mengelola PLTMH, sehingga ketika tidak lagi dilakukan pendampingan masyarakat bisa secara mandiri mengelola PLTMH. Pembangunan PLTMH dilakukan dengan melibatkan masyarakat. Masyarakat kemudian juga diberikan pelatihan penggunaan dan perawatan PLTMH. Sumber energi yang dihasilkan PLTMH sangat bergantung dengan persediaan debit air yang tentunya juga tergantung dengan kondisi hutan di sekitar Lebak Picung. Berkaitan dengan hal tersebut PLN melalui PPLH juga melakukan pelatihan rehabilitasi hutan dan lahan, pengumpulan bibit dari dalam hutan, pembibitan, serta penanaman. Pengembangan ekonomi produktif juga dilakukan agar masyarakat dapat memanfaatkan listrik pada siang hari untuk membantu pemasukan rumah tangga. Melalui identifikasi potensi di Lebak Picung, sumber energi listrik dari PLMTH bisa digunakan untuk proses pembuatan gula semut yang merupakan proses lebih lanjut dari pengolahan gula aren, sehingga mampu meningkatkan nilai tambah bagi masyarakat. Program pendukung PLTMH yaitu pengembangan ekonomi 
produktif dan rehabilitasi hutan dan lahan dijalankan sampai proyek kerjasama antara PPLH dan PLN selesai, namun sayangnya pengembangan ekonomi produktif melalui pembuatan gula tidak dilakukan lagi oleh masyarakat. Tidak adanya pendampingan membuat program lain yang ditujukan agar masyarakat mampu meningkatkan ekonomi keluarga dengan memanfaatkan listrik PLTMH pada siang hari ternyata tidak berkelanjutan. Kelembagaan yang ditujukan untuk mengelola penggunaan dan perawatan PLTMH berlangsung secara kontinu. Masyarakat memiliki jadwal jaga rutin tiap malam dan terdapat sistem pembayaran tiap bulan untuk uang kas yang ditujukan untuk perawatan peralatan PLTMH.

Setelah melewati masa perencanaan, pembangunan, running-test, serta pendampingan selama tahun 2009 , PLTMH resmi menjadi pembangkit listrik bagi masyarakat Lebak Picung pada tahun 2010 hingga saat ini. Selama tahun 2010, PLTMH mengalami kematian selama 4 bulan karena debit air sungai Ciambulaung yang sedikit saat musim hujan. Pendampingan pada masyarakat telah berakhir sesuai dengan kerjasama yang dilakukan pendamping dan pelaksana program yaitu PPLH IPB dengan pihak perusahaan yaitu PLN. Sayangnya pendampingan ini sudah tidak dijalankan saat masyarakat belum sepenuhnya mandiri. Terdapat informasi yang belum dimiliki sasaran program seperti teknis penggantian alat oleh PLN jika terjadi kerusakan pada PLTMH.

Program pemberdayaan yang dilakukan dengan bekerjasama dengan mitra memang memberikan manfaat bagi perusahaan, yaitu program dijalankan dengan melibatkan ahli-ahli dalam bidangnya. Namun sayangnya komunikasi yang dilakukan oleh mitra sebagai tangan kanan perusahaan justru membuat sasaran program lebih mengenal organisasi mitra pelaksana dibanding PLN. Tidak adanya komunikasi secara langsung yang dilakukan PR PLN juga membuat informasi tentang perusahaan tidak sepenuhnya dimiliki sasaran program.

\section{Kondisi Geografis}

Kampung Lebak Picung berada dalam wilayah Desa Cibeber yang saat ini berubah menjadi Desa Hegarmanah, Kecamatan Cibeber, Kabupaten Lebak. Labakpicung secara administratif masuk ke RW 04 Desa Hegarmanah dengan luas wilayah 230,98 ha, dan hanya 6,41 persen atau 14,81 ha saja yang didirikan bangunan. Sebagian besar wilayah Lebak Picung di dominasi oleh hutan dan kebun campuran. Handini (2010) juga mengungkapkan bahwa 70,48 persen wilayah Lebak Picung atau sekitar 162,8 ha wilayah kampung berada di kawasan TNGHS. Adapun batas-batas kampung yaitu, bagian utara berbatasan dengan Desa Ciusul, bagian barat berbatasan dengan kampung Karangropong dan Taman Nasional Gunung Halimun Salak, dan bagian selatan serta timur berbatasan dengan TNGHS yang dibatasi oleh sungai Ciambulaung.

Kampung Lebak Picung terletak di lembah yang dapat di akses melalui jalan berbatu dengan lebar 1,5 - $2 \mathrm{~m}$ diantara jurang dan tebing. Akses jalan menuju Lebak Picung dapat dilalui dengan kendaraan sepeda motor atau berjalan kaki. Perjalanan dari kampung terdekat (Kampung Hegarmanah) ke Kampung Lebak Picung adalah sekitar 20 menit dengan sepeda motor atau 1 jam dengan berjalan kaki. Hal ini dikarenakan kondisi jalan yang masih terbuat dari bebatuan dengan kemiringannya cukup terjal.

Rumah penduduk didirikan dipinggir-pinggir Sungai Ciambulaung di sekitar perbukitan yang mengitari lembah. Adanya potensi sungai di Lebak Picung dan sebagian besar wilayahnya masih di dominasi dengan hutan dan pepohonan membuat daerah ini menjadi daerah yang memiliki potensi untuk dikembangkan PLTMH.

\section{Kondisi Sosial}

Masyarakat yang berada di Kecamatan Cibeber sebagian besar merupakan suku Sunda dan beberapa juga terdapat masyarakat pendatang dari luar suku Sunda. Sebagian besar masyarakat di Dusun Lebak Picung digolongkan kedalam masyarakat kasepuhan. Adapun masyarakat yang tidak digolongkan ke dalam kasepuhan adalah masyarakat pendatang yang menikah dengan orang Lebak Picung. Secara formal, ketua RW memegang peranan tertinggi di Lebak Picung, namun ada juga kelembagaan yang dimiliki masyarakat kasepuhan di Lebak Picung. Pada masyarakat Lebak Picung, kelembagaan kasepuhan memiliki peranan yang lebih dibandingkan kelembagaan formal.

Jumlah penduduk di Lebak Picung berdasarkan data RW setempat pada tahun 1989 adalah 120 orang, tahun 1997 meningkat menjadi 153 orang, dan pada tahun 2007 adalah sebanyak 180 orang, pada saat penelitian dilakukan pendataan terhadap jumlah tiap anggota rumah tangga pada seluruh rumah didapatkan hasil penduduk Lebak Picung adalah sebanyak 180 orang. Diperkirakan jumlah penduduk akan mengalami peningkatan di masa yang akan datang. Hal ini disebabkan oleh adanya sistem sosial yang terbuka, dimana masyarakat bisa keluar masuk dan menetap di kampung ini. Selain itu, adanya tradisi di masyarakat untuk menikah muda, bisa menjadi penyebab dalam peningkatan jumlah penduduk. Pertambahan jumlah penduduk ini menjadi salah satu alasan pentingnya pengadaan listrik untuk mendukung kehidupan dan membantu dalam pencapaian kesejahteraan mereka.

Masyarakat Lebak Picung memiliki hubungan yang erat satu sama lain. Hal ini bisa menjadi potensi untuk dikembangkannya sebuah kelembagaan yang ditujukan untuk mengatur operasionalisasi program pemberdayaan. Ini bisa menjadi modal sosial dengan adanya serangkaian nilai-nilai atau norma-norma informal yang dimiliki bersama diantara para anggota suatu kelompok yang memungkinkan terjalinnya kerjasama diantara mereka. Adanya modal sosial ini memudahkan keberhasilan program pemberdayaan diterapkan dan keberhasilan bagi masyarakat dalam mendapatkan kesejahteraan dari kerjasama yang mereka lakukan

\section{Karakteristik Responden}

Berdasarkan Tabel 2 diketahui bahwa dari 52 responden, 35 responden (67 persen) berjenis kelamin laki-laki dan tujuh belas responden (33 persen) lainnya berjenis 
kelamin perempuan. Dua rumah tangga diwakili oleh perempuan (istri), karena suaminya usianya sudah di atas 80 tahun dan dalam keadaan tidak sehat, sedangkan perempuan yang lain mewakili suaminya yang sedang bekerja.

Tabel 2. Jumlah dan Presentase Responden Berdasarakan Jenis Kelamin

\begin{tabular}{cccc}
\hline \multirow{2}{*}{ No $_{0}$} & \multirow{2}{*}{ Jenis Kelamin } & \multicolumn{2}{c}{ Jumlah } \\
\cline { 3 - 4 } & & $\mathrm{N}$ & Persen \\
\hline 1. & Laki-Laki & 35 & 67 \\
2. & Perempuan & 17 & 33 \\
\hline & Jumlah & 52 & 100 \\
\hline
\end{tabular}

Responden dalam penelitian merupakan kepala keluarga, sehingga usia termuda yang ditemukan pada responden adalah 23 tahun. Berdasarkan kategori usia, responden dikelompokkan menjadi empat, yaitu usia 21-30 tahun, 31-40 tahun, 41-50 tahun, dan usia di atas 50 tahun. Berdasarkan data ini diketahui bahwa sebagian besar responden berumur di bawah 40 tahun, yaitu terdapat lima belas responden (29 persen) berusia 21-30 tahun dan enam belas responden (31 persen) telah berusia 31-40 tahun. Responden dengan usia 41-50 tahun adalah sebanyak sebelas orang (21 persen), dan terdapat sepuluh responden (19 persen) yang telah berusia di atas 50 tahun.

Sarana pendidikan yang ada di Lebak Picung hanya Sekolah Dasar saja, hal ini menjadi salah satu sebab sebagian besar responden rata-rata memiliki latar belakang pendidikan hanya sampai sekolah dasar, bahkan cukup banyak juga yang tidak bersekolah. Akses ke tempat pendidikan seperti SMP, SMA/SMK pun cukup jauh dan harus menaiki lembah terlebih dahulu.

Tabel 3. Jumlah dan Presentase Responden Menurut Tingkat Pendidikan yang Ditamatkan

\begin{tabular}{clcc}
\hline \multirow{2}{*}{ No. } & & \multicolumn{2}{c}{ Jumlah } \\
\cline { 3 - 4 } & & Tingkat Pendidikan & Persen \\
\hline 1 & Tidak Tamat & 22 & 42 \\
2 & Tamat SDMMadrasah Ibtidaiyah & 28 & 54 \\
3 & Tamat SMPMadrasah Tsanawiyah & 0 & 0 \\
4 & Tamat SMA SMKMMadrasah Aliyah & 2 & 4 \\
5 & TamatPerguruan Tinggi & 0 & 0 \\
\hline & $\quad$ Jumlah & 52 & 100 \\
\hline
\end{tabular}

Berdasarkan Tabel 3 diketahui bahwa sebgaian besar responden memiliki latar belakang pendidikan sekolah dasar yaitu sebanyak 28 orang (54 persen), bahkan terdapat 22 responden ( 42 persen) tidak tamat pendidikan formal sama sekali, dan hanya dua responden (4 persen) yang berpendidikan akhir SMA/SMK. Walaupun sebagian besar responden memiliki latar belakang pendidikan yang tidak terlalu tinggi, namun mereka cukup memahami bahasa Indonesia.

\section{PENILAIAN MASYARAKAT TERHADAP PELAKSANAAN COMMUNITY RELATIONS PROGRAM PLTMH}

Berdasarkan Gambar 4, Secara keseluruhan PLTMH Lebak Picung mampu memberikan aliran listrik ke semua rumah tangga di Lebak Picung yaitu sebanyak lima pulub dua KK. Namun sayangnya PLTMH di Lebak Picung sempat berhenti mengalirkan listrik selama empat bulan karena debit air sungai yang rendah ${ }^{4}$.

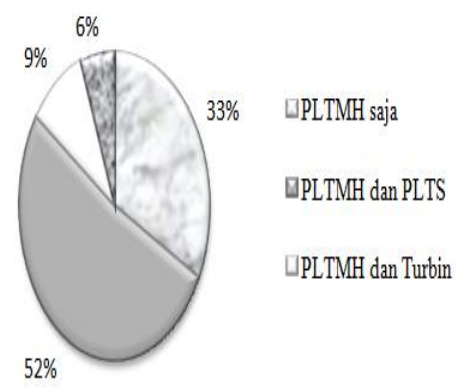

Gambar 4. Presentase Pemakaian Pembangkit Listrik oleh Rumah Tangga di Lebak Picung

Tiap pembangkit listrik memiliki kelebihan dan kekurangan masing-masing, sehingga tiap responden memiliki pendapat yang berbeda tentang kemampuan sumber pembangkit listrik yang mampu memenuhi kebutuhan listrik dalam rumah tangga mereka. Jika dilihat secara keseluruhan, Gambar 5 memperlihatkan bahwa sebanyak $46 \mathrm{KK}$ (88 persen) menyatakan bahwa PLTMH lebih mampu memnuhi kebutuhan listrik rumah tangga mereka dengan catatan saat PLTMH tersebut berfungsi secara normal (tidak mati karena debit airnya yang rendah). Terdapat lima KK (10 persen) yang lain berpendapat bahwa PLTS lebih mampu memenuhi kebutuhan listrik rumah tangga mereka karena selalu bisa diandalkan karena tidak seperti PLTMH yang sangat tergantung dengan ketersediaan debit air sungai. Terdapat 2 persen yaitu satu KK yang menyatakan bahwa PLTS dan PLTMH sama-sama mampu memenuhi kebutuhan listrik rumah tangganya. PLTMH memiliki kelebihan dari daya yang dihasilkan bisa dimanfaatkan untuk menyalakan berbagai alat elektronik, sedangkan PLTS dengan daya yang dihasilkannya sangat kecil, hanya mampu menyalakan sekitar 2 lampu dengan jangka waktu yang tidak lebih dari 10 jam per harinya, namun PLTS bisa memenuhi kebutuhan listrik keluarga saat PLTMH sedang tidak berfungsi dengan baik seperti saat kemarau. 


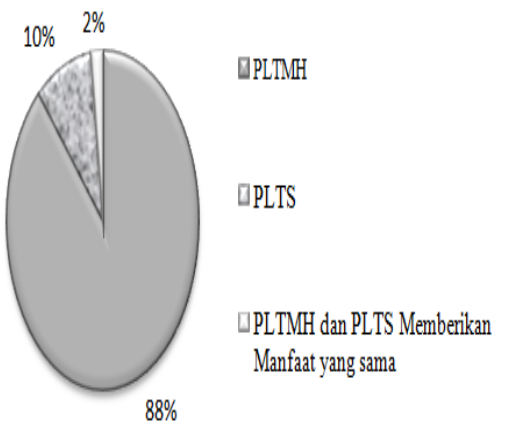

Gambar5. Presentase Pembangkit Listrik yang Lebih Memenuhi Kebutuhan Listrik Rumah Tangga di Lebak Picung

\section{Pelaksanaan Program PLTMH}

\section{Tingkat Keterlibatan dalam Program}

Tingkat keterlibatan dalam program melihat bagaimana keterlibatan masyarakat sebagai penerima program dalam proses perencanaan PLTMH, pembangunan PLTMH, sampai pengelolaan PLTMH. Pengukuran pada keterlibatan masyarakat dalam program ditujukan untuk melihat hubungan partisipasi masyarakat dalam program dengan citra yang terbentuk terhadap perusahaan. Citra yang kurang bagus dimungkinkan timbul karena keterlibatan masyarakat dalam program yang relatif rendah sehingga tidak mendapatkan informasi yang memadai tentang program dan perusahaan.

Sebanyak 29 responden (56 persen) memiliki total skor diantara 22-28 dan masuk dalam kategori responden dengan tingkat keterlibatan tinggi dalam program PLTMH, hal ini bisa ditunjukkan dengan perannya selain rutin ronda, pembangunan, dan hadir dalam perencanaan, beberapa responden juga berperan sebagai pengurus aktif maupun perannya dengan selalu menjaga kelancaran air sungai dengan tidak membuang sampah sembarangan maupun mengingatkan warga sekitar untuk menjaga sungai. Terdapat 23 responden (44 persen) memiliki total skor antara 15-21 dan masuk ke dalam kategori responden dengan tingkat keterlibatan sedang dalam program PLTMH. Responden dengan total skor 15-21 salah satunya adalah walaupun tidak terlibat sebagai pengurus aktif namun ikut serta dalam pembangunan dan melakukan ronda sesuai jadwal.

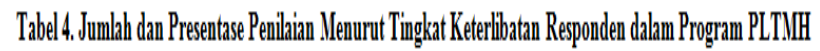

\begin{tabular}{|c|c|c|c|}
\hline \multirow{2}{*}{$\aleph_{0}$} & \multirow{2}{*}{ Tinghat Keterlibatan Responden (skor) } & \multicolumn{2}{|c|}{ Jumlah } \\
\hline & & I & Persen \\
\hline 1. & $\operatorname{Rendan}(\leq 13)$ & 0 & 0 \\
\hline 2. & Sedang(14-21) & 23 & H4 \\
\hline 3. & $\operatorname{Tingg}(222)$ & 29 & 56 \\
\hline & Jumlah & 52 & 100 \\
\hline
\end{tabular}

Hasil ini menunjukkan bahwa sebagian besar responden atau rumah tangga memliki keterlibatan yang tinggi dalam program PLTMH, dimana masing-masing rumah tangga mengetahui bahwa PLN memiliki program PLTMH, PLN juga melibatkan peran serta masyarakat dalam perencanaan, pembangunan, maupun menumbuhkan kemandirian masyarakat dengan mengurus secara mandiri pengelolaan PLTMH sehingga masyarakat memiliki kepedulian dan turut menjaga keberlangsungan operasionalisasi PLTMH maupun ikut serta menjaga lingkungan khususnya ketersediaan dan kelancaran air sungai sebagai sumber utama PLTMH.

\section{Manfaat Program}

Manfaat Program adalah sejauhmana program PLTMH berguna bagi masyarakat. Manfaat program melihat sejauhmana PLTMH dinilai telah membantu memenuhi kebutuhan listrik di Lebak Picung, manfaat yang dirasakan dalam pemenuhan listrik rumah tangga dibandingkan pembangkit listrik lain seperti generator maupun PLTS, sejauhmana PLTMH PLN memberikan manfaat pada pemenuhan kebutuhan informasi yang didapatkan rumah tangga melalui akses pada media dengan adanya listrik, manfaat di bidang pendidikan dengan peningkatan minat belajar anggota keluarga dengan adanya listrik, peningkatan perekonomian keluarga, maupun perkembangan pada Lebak Picung secara keseluruhan.

\section{Tabel5. Jumlah dan Presentase Responden Menurut Mlanfaat Program PLTNH}

\begin{tabular}{cccc}
\hline \multirow{2}{*}{ No. } & \multirow{2}{*}{ Manfaat Program PLTMH(skor) } & \multicolumn{2}{c}{ Jumlah } \\
\cline { 3 - 4 } & & N & Persen \\
\hline 1. & Kurang bemanfaat $(\leq 11)$ & 0 & 0 \\
2. & Cukup bermanfaat (12-18) & 32 & 62 \\
3. & Sangat Bemanfaat $(\geq 19)$ & 20 & 38 \\
\hline & Jumlah & 52 & 100 \\
\hline
\end{tabular}

Berdasarkan Tabel 5 diketahui bahwa terdapat 32 responden (62 persen) dengan skor total 12-18 yang menyatakan bahwa PLTMH dari PLN cukup bermanfaat, khususnya bagi pemenuhan listrik rumah tangga maupun membantu aktivitas lainnya seperti pemenuhan informasi sampai meningkatkan interaksi antar warga di malam hari. Sedangkan dua puluh responden (38 persen) yang lain menyatakan bahwa PLTMH dari PLTMH sangat bermanfaat karena PLTMH telah membantu dalam membantu memenuhi kebutuhan listrik di Lebak Picung, dengan adanya listrik anggota rumah tangga mendapatkan kemudahan terhadap akses informasi dari media massa seperti televisi, meningkatkan minat belajar anggota keluarga, secara tidak langsung juga listrik ikut membantu meningkatkan perekonomian keluarga sampai interaksi antar warga maupun anggota keluarga yang semakin intens di malam hari dengan adanya listrik. Salah satu responden menyatakan bahwa:

“....dengan adanya listrik dari PLTMH,
kegiatan kami jadi lebih mudah. Masak
jadi lebih mudah, tinggal pakai magic
com aja, disini juga jadi lebih terang
kalau malam...” (Mr, 45 tahun)

Manfaat PLTMH lainnya juga dirasakan oleh responden:

“....anak saya ini rajin belajar, tulisannya juga bagus, kalau malam biasanya suka baca-baca buku sekolahnya...."(Aws, 32 tahun) 
“...listrik itu bantu perekonomian keluarga saya teh, karena saya kan bikin meubel tuh dibelakang rumah, ya walaupun kecil-kecilan tapi kan buat ngalusin kayunya juga pake listrik..."(Plg, 50 tahun)

“...ya PLN uda banyak membantu warga, bantu pembangunan mesjid, trus jadi ada listrik kalo lagi banyak air. Pengennya sih, bisa nyala siang malam dan dayanya tambah besar, soalnya kalo mati kaya sekarang kan jadinya belum bisa memenuhi kebutuhan listrik di sini..." (Msj, 43 tahun)

Secara keseluruhan, responden menyatakan bahwa listrik yang dihasilkan oleh PLTMH telah memberikan manfaat yang berarti terutama di tingkat rumah tangga. Responden menyatakan bahwa listrik memudahkan mereka dalam melakukan berbagai pekerjaan rumah tangga salah satunya seperti kemudahan dalam menanak nasi. PLTMH mampu menghasilkan daya yang lebih tinggi dibandingkan dengan pembangkit listrik lain sehingga warga bisa menggunakan berbagai alat elektronik dengan biaya iuran koperasi tiap bulan yang relatif murah. Sayangnya dalam kondisi kemarau dimana sungai memiliki debit air yang rendah, PLTMH tidak beroperasi sehingga tidak mampu memberikan pasokan listrik untuk memnuhi kebutuhan listrik di Lebak Picung.

\section{Penilaian Terhadap Pelaksanaan PLTMH}

Variabel pelaksanaan PLTMH menilai dari keterlibatan penerima program pada program PLTMH serta kesesuaian manfaat program dengan kebutuhan penerima program. Penilaian terhadap pelaksanaan PLTMH ini dilakukan untuk melihat bahwa partisipasi penerima program dalam perencanaan hingga operasionalisasi dan perawatan PLTMH berpengaruh terhadap citra perusahaan yang terbentuk. Manfaat yang sesuai dengan kebutuhan masyarakat dari program yang dijalankan juga memiliki perngaruh pada pembentukan citra perusahaan.

Tabel 6. Jumlah dan Presentase Responden Berdasarkan Penilaian Terhadap Pelaksanaan PLTMH

\begin{tabular}{cccc}
\hline \multirow{2}{*}{ No. } & \multirow{2}{*}{ Program PLTIIH(skor) } & \multicolumn{2}{c}{ Jumlah } \\
\cline { 3 - 4 } & & N & Persen \\
\hline 1 & Dilaksanakan dengan kurang baik (14-26) & 0 & 0 \\
2 & Dilaksanakan dengan cukup baik (27-39) & 27 & 52 \\
3 & Dilaksanakan dengan sangat baik (40-52) & 25 & 48 \\
\hline \multicolumn{2}{c}{ Skor } & 52 & 100 \\
\hline
\end{tabular}

Penilaian tentang program PLTMH dilihat dari keterlibatan responden dalam program serta manfaat yang dirasakan responden dengan adanya program PLTMH. 25 responden (48 persen) menyatakan bahwa program PLTMH dilaksanakan dengan sangat baik, sedangkan 27 responden (52 persen) lainnya menilai bahwa program PLTMH dilaksanakan dengan cukup baik. Tidak ada sama sekali responden yang mengkategorikan program PLTMH dilaksanakan dengan kurang baik.

\section{Proses Pembentukan Citra}

Pembentukan citra terdiri dari beberapa tahapan, yang pertama adalah penangkapan informasi, kemudian perhatian, kemudian pemahaman. Semakin sengaja suatu program dijalankan dengan menginformasikan kepada masyarakat maka tingkat penangkapan informasi yang dimiliki oleh masyarakat sebagai penerima program dari perusahaan akan semakin tinggi. Penangkapan informasi pada sasaran program dan pelaksanaan program akan mempengaruhi tahap pembentukan citra berikutnya yaitu tingkat perhatian terhadap program. Perhatian pada program kemudian berpengaruh pada pemahaman yang dimiliki sasaran program terhadap pembentukan citra.

\section{Tingkat Penangkapan Informasi (Exposure)}

Dalam penelitian ini, tingkat penangkapan informasi dinilai dari sejauh mana sasaran program mengetahui atau menyadari adanya implementasi program PLTMH. Tingkat penangkapan informasi digunakan untuk melihat informasi yang dimiliki responden tentang program PLTMH di Lebak Picung, hingga sejauh mana responden mengetahui tentang PLN dan upaya yang dilakukan PLN.

Tabel 7. Jumlah dan Presentase Responden Berdasarkan Tingkat Penangkapan Informasi (Exposure)

\begin{tabular}{clcc}
\hline \multirow{2}{*}{ No. } & \multirow{2}{*}{ Tingkat Penangkapan Informasi (skor) } & \multicolumn{2}{c}{ Jumlah } \\
\cline { 3 - 4 } & & N & Persen \\
\hline 1 & Rendah( $(\leq 11)$ & 0 & 0 \\
2 & Sedang (12-18) & 32 & 62 \\
3 & Tinggi $(\geq 19)$ & 20 & 38 \\
\hline \multicolumn{2}{c}{ Jumlah } & 52 & 100 \\
\hline
\end{tabular}

Berdasarkan data Tabel 7 diketahui bahwa sebanyak dua puluh responden responden (38 persen) memiliki skor keseluruhan di atas 19 yang berarti mereka memiliki informasi yang tinggi tentang program PLTMH maupun PLN sebagai perusahaan penyelenggara PLTMH. Tiga puluh dua responden (62 persen) memiliki skor 12-18 yang berarti memiliki cukup informasi atau tingkat penangkapan informasi sedang tentang program PLTMH.

$$
\begin{aligned}
& \text { “...sebelumnya ya nggak tau kalau ada } \\
& \text { PLN, baru pas ada PLTMH tahu tentang } \\
& \text { PLN....” (Sgn, } 47 \text { tahun) }
\end{aligned}
$$

Meskipun sebagian responden menilai bahwa PLN belum menjalankan program PLTMH secara terus menerus karena tidak adanya pengontrolan yang dilakukan perusahaan ke Lebak Picung, namun secara keseluruhan responden memiliki informasi yang memadai tentang program PLTMH

\section{Tingkat Perhatian (Attention)}

Tingkat perhatian menilai sejauh mana ketertarikan penerima program untuk mengetahui lebih lanjut tentang kegiatan PLTMH, yang dilihat melalui ketertarikan serta apa yang dirasakan oleh responden terhadap program PLTMH dari PLN. 
Tabel8. Jumlah dan Presentase Responden Berdasarkan Tingkat Perhatian (Attention)

\begin{tabular}{clccc}
\hline \multirow{2}{*}{ No. } & \multirow{2}{*}{ Tingkat Perhatian (skor) } & \multicolumn{2}{c}{ Jumlah } \\
\cline { 3 - 5 } & & N & Persen \\
\hline 1 & Rendah $(99)$ & 0 & 0 \\
2 & Sedang $(10-15)$ & 37 & 71 \\
3 & Tinggi $(216)$ & 15 & 29 \\
\hline \multicolumn{2}{r}{} & Total & 52 & 100 \\
\hline
\end{tabular}

Secara keseluruhan tingkat perhatian responden merupakan tahapan lebih lanjut setelah penangkapan informasi dalam proses pembentukan citra. Tingkat perhatian dilihat berdasarkan ketertarikan sasaran program terhadap PLN dan program PLTMH. Ketertarikan ini salah satunya dinilai dari keyakinan terhadap program dan perusahaan. Tingkat perhatian dinilai dari 5 pertanyaan. Terdapat lima belas responden (29 persen) memiliki tingkat perhatian yang tinggi terhadap program yang dilihat melalui ketertarikan responden terhadap usaha yang dilakukan PLN khususnya melalui program PLTMH di tempat mereka tinggal. Responden merasa bahwa PLN sangat berusaha untuk hidup berdampingan dengan siapapun yang terlihat dari kesungguhan PLN untuk menjangkau mereka walaupun berada di lokasi yang cukup sulit dijangkau, ketertarikan mereka diketahui pula dari pengetahuan yang dimiliki dari tiap pelaksanaan kegiatan yang berhubungan dengan PLTMH dari mulai perencanaan sampai pengelolaan.

Terdapat 37 responden (71 persen) dengan total skor 12 18 yang berarti memiliki tingkat perhatian sedang. Sebagian besar tingkat perhatian responden yang masuk dalam kategori perhatian sedang ini dipengaruhi oleh ketidakstabilan PLTMH yang masih sering mengalami kematian khususnya saat musim kemarau. Responden juga menyatakan bahwa PLN belum sepenuhnya berusaha hidup berdampingan dengan masyarakat karena tidak pernah mengadakan kunjungan atau pengontrolan ke daerah mereka.

\section{Tingkat Pemahaman (Comprehensive)}

Tingkat Pemahaman (Comprehensive) adalah sejauh mana pengetahuan dan penilaian individu sasaran program tentang implementasi program community relations. Variabel ini mengukur pernyataan tentang pemahaman terhadap manfaat PLTMH secara keseluruhan, penilaian terhadap PLN sebagai sahabat bagi warga karena mampu memenuhi kebutuhan listrik, serta kebersediaan menjadi pengurus dalam program pemberdayaan yang diadakan PLN maupun kebersediaan jika PLN melakukan kegiatan lain di Lebak Picung.

Tabel9. Jumlah dan Presentase Responden Berdasarkan Tingkat Pemahaman (Comprehensive)

\begin{tabular}{ccccc}
\hline \multirow{2}{*}{$N_{0 .}$} & \multirow{2}{*}{ Tingkat Pemahaman } & \multicolumn{2}{c}{ Jumlah } \\
\cline { 3 - 5 } & & N & Persen \\
\hline 1 & Rendah( $(\leq 11)$ & & 0 \\
2 & Sedang (12-18) & 40 & 77 \\
3 & Tinggi $(218)$ & & 12 & 23 \\
\hline & & Jumlah & 52 & 100 \\
\hline
\end{tabular}

Berdasarkan Tabel 9 diketahui bahwa sebagian besar responden masuk ke dalam kategori tingkat pemahaman sedang dengan skor total 12-18, yaitu sebanyak empat puluh responden (77 persen). Tingkat pemahaman yang dimiliki responden ini dinyatakan dengan kesediaan responden menerima kegiatan atau program baru di Lebak Picung yang diadakan oleh PLN, namun keberatan jika menjadi pengurus atau pengelola. Sebanyak dua puluh responden ( 23 persen) memiliki skor diatas 18 memiliki tingkat perhatian yang tinggi, mereka menyatakan bahwa PLN sudah menjadi sahabat karena berbagai manfaat yang telah dirasakan dari program PLTMH. Responden juga menyatakan bersedia jika PLN mengadakan program atau kegiatan lain di sekitar tempat tinggal mereka dan siap menjadi pengurus atau pengelola dalam program baru tersebut.

\section{Proses Pembentukan Citra}

Proses pencitraan atau proses pembentukan citra adalah proses pemaknaan program pada sasaran yang diawali dari adanya penangkapan informasi (exposure), dilanjutkan dengan perhatian (attention) terhadap program, dan pemahaman (comprehensive) pada program.

\section{Tabel 10. Jumlah dan Presentase Responden Berdasarkan Proses Pembentukan Citra}

\begin{tabular}{|c|c|c|c|}
\hline \multirow{2}{*}{$\mathrm{N}_{0}$. } & \multirow{2}{*}{ Proses Pembentukan Citra } & \multicolumn{2}{|c|}{ Jumlah } \\
\hline & & N & Persen \\
\hline 1 & Bunk (s11) & 0 & 0 \\
\hline 2 & Cukup baik (12-18) & 35 & 67 \\
\hline 3 & Sangat baik (218) & 17 & 33 \\
\hline & Jumlah & 52 & 100 \\
\hline
\end{tabular}

Berdasarkan Tabel 10 diketahui bahwa dari 52 responden, 35 responden (67 persen) memiliki skor keseluruhan proses pembentukan citra antara 12-18 yang berarti proses pembentukan citra pada responden cukup baik. Hal ini ditunjukkan dari tingkat penangkapan informasi, tingkat perhatian, dan tingkat pemahaman yang masuk ke dalam kategori sedang, karena tidak memiliki informasi yang memadai tentang PLTMH dan upaya yang dilakukan perusahaan, belum memahami dengan benar tentang upaya perusahaan, serta belum merasa bahwa PLTMH telah sesuai dengan apa yang diharapkan, namun responden juga tidak memiliki penilaian yang terlalu negatif tentang PLTMH maupun perusahaan. Sebanyak tujuh belas responden (33 persen) memiliki proses pembentukan citra yang sangat baik yang terlihat dari tingkat penangkapan informasi, tingkat perhatian, serta tingkat pemahaman yang sangat baik. Responden memahami program PLTMH dan upaya yang dilakukan perusahaan, merasa bahwa upaya yang dilakukan perusahaan telah memberikan dampak yang positif, serta memiliki tingkat penerimaan yang relatif tinggi.

Secara keseluruhan, responden memiliki proses pembentukan citra yang baik, karena tergolong dalam kategori proses pembentukan citra cukup bak dan sangat baik, serta tidak ada yang memiliki proses pembentukan citra yang kurang. Responden memiliki informasi yang memadai (exposure), perhatian yang baik (attention), serta pemahaman (comprehensive) baik. 


\section{Citra Perusahaan}

Citra perusahaan adalah citra keseluruhan tentang organisasi yang terbentuk pada individu yaitu responden. Penelitian ini memfokuskan citra perusahaan yang terbentuk pada sasaran program melalui implementasi community relations PLN program Pembangkit Listrik Tenaga Mikro Hidro (PLTMH). Citra PLN dilihat melalui penilaian responden terhadap personality, reputation, corporate identity, dan value ethic perusahaan.

\section{Penilaian Terhadap Personality Perusahaan}

Penilaian pada personality perusahaan adalah sejauh mana publik sasaran menilai perusahaan sebagai perusahaan yang dipercaya, perusahaan yang mempunyai tanggung jawab sosial.

Tabelll. Jumlah dan Presentase Responden Berdasarkan Penilaian Terhadap Personality Perusahaan

\begin{tabular}{|c|c|c|c|}
\hline \multirow{2}{*}{$N_{0}$} & \multirow{2}{*}{ Penilaian Terhadap Personality Perusahaan } & \multicolumn{2}{|c|}{ Jumlah } \\
\hline & & $\mathrm{N}$ & Persen \\
\hline 1 & Kurang baik (s11) & 0 & 0 \\
\hline 2 & Cukup baik (12-18) & 44 & 85 \\
\hline 3 & Sangat baik (218) & 8 & 15 \\
\hline & Jumlah & 52 & 100 \\
\hline
\end{tabular}

Sebanyak 44 responden (85 persen) menilai personality perusahaan dengan cukup baik. Responden menyatakan bahwa PLN telah melakukan langkah nyata dalam memberdayakan masyarakat salah satunya melalui program yang dilakukan di lokasi mereka, namun tidak sepenuhnya responden menilai PLN sebagai perusahaan dengan kinerja yang baik maupun sebagai perusahaan yang dapat dipercaya, karena adanya pengalaman yang dirasakan responden. Responden menyatakan terdapat beberapa janji PLN yang belum dilaksanakan serta tidak ada kontak yang mereka bisa hubungi dari pihak PLN jika terjadi sesuatu dengan PLTMH. Salah satu tolak ukur kinerja PLN dinilai masyarakat dari kemampuan PLTMH dalam memberikan aliran listrik. Sedangkan 8 responden (15 persen) lain menyatakan bahwa PLN memiliki personality yang sangat baik.

\section{Penilaian Terhadap Reputation Perusahaan}

Penilaian pada reputation perusahaan adalah keyakinan positif publik sasaran berdasarkan pengalaman sendiri maupun pihak lain terhadap manfaat yang diberikan perusahaan, dalam penelitian ini dikhususkan pada program PLTMH yang diberikan PLN pada masyarakat di Lebak Picung.

Tabel 12. Jumlah dan Presentase Responden Berdasarkan Penilaian Terhadap Reputation Perusahaan

\begin{tabular}{|c|c|c|c|}
\hline \multirow[b]{2}{*}{$\mathrm{N}_{0 .}$} & \multirow{2}{*}{ Penilaian Terhadap Reputation Perusahaan } & \multicolumn{2}{|c|}{ Jumlah } \\
\hline & & $\mathrm{N}$ & Persen \\
\hline 1 & Kurang baik $(\leq 9)$ & 0 & 0 \\
\hline 2 & Cukup baik (10-15) & 31 & 60 \\
\hline 3 & Sangat baik ( $\geq 15)$ & 21 & 40 \\
\hline & Jumlah & 52 & 100 \\
\hline
\end{tabular}

Berdasarkan Tabel 12 diketahui bahwa terdapat 31 responden (60 persen) yang menilai reputation perusahaan dengan cukup baik. Reputation PLN pada responden didasarkan pada penilaian mereka terhadap
PLTMH yang dilakukan PLN. Responden menilai bahwa PLN belum sepenuhnya meningkatkan hubungan sosial antara PLN dengan mereka, responden tidak menilai terlalu negatif namun juga tidak menunjukkan penilaian reputation yang sepenuhnya baik. Sebanyak 21 responden (40 persen) menilai PLN sebagai perusahaan dengan reputation yang sangat baik. Responden menyatakan bahwa PLN telah menjadi perusahaan yang memiliki kepedulian tinggi terhadap kebutuhan listrik masyarakat karena mampu menjangkau lokasi tempat tinggal mereka yang berada di daerah yang cukup sulit dijangkau. Melalui PLTMH, PLN juga telah menunjukkan reputation sebagai perusahaan yang tidak hanya mengejar keuntungan semata namun juga ikut peduli dengan kesejahteraan masyarakat.

\section{Penilaian Terhadap Value Ethic Perusahaan}

Penilaian pada Value ethics Perusahaan, adalah sejauh mana publik menganggap perusahaan memiliki nilai-nilai yang baik.

Tabel 13. Jumlah dan Presentase Responden Berdasarkan Penilaian Terhadap Value Ethic Perusahaan

\begin{tabular}{clcc}
\hline \multirow{2}{*}{ No. } & \multirow{2}{*}{ Penilaian Terhadap Value Ethic Perusahaan } & \multicolumn{2}{c}{ Jumlah } \\
\cline { 3 - 4 } & & N & Persen \\
\hline 1 & Kurang baik $(\leq 9)$ & 0 & 0 \\
2 & Cukup baik $(10-15)$ & 35 & 67 \\
3 & Sangat balk $(216)$ & 17 & 33 \\
\hline \multicolumn{2}{c}{ Jumlah } & 52 & 100 \\
\hline
\end{tabular}

Berdasarkan data pada Tabel 13, sebanyak 35 responden (67 persen) memiliki skor untuk value ethic perusahaan antara 10-15 yang berarti mereka memiliki penilaian yang cukup baik terhadap value ethic PLN. Menurut responden PLN telah menjadi perusahaan dengan value ethic yang cukup baik, PLN merupakan perusahaan yang bermanfaat bagi lingkungan maupun sebagai perusahaan yang menghargai norma dan nilai yang ada di masyarakat. Terdapat tujuh belas responden (33 persen) yang menilai PLN sebagai perusahaan dengan value ethic yang sangat baik, karena PLN khususnya dalam menjalankan PLTMH di Lebak Picung mendapatkan dukungan dari tokoh-tokoh terkemuka dan masyarakat di Lebak Picung, PLN juga memberikan banyak manfaat.

\section{Penilaian Terhadap Corporate Identity Perusahaan}

Penilaian pada Corporate Identity Perusahaan adalah sejauh mana publik sasaran mengetahui dan menilai komponen pengenal perusahaan seperti logo, dll. Secara keseluruhan penilaian terhadap corporate identity PLN ditunjukkan melalui data pada Tabel 14. Terdapat satu responden ( 2 persen) yang memiliki pengetahuan buruk terhadap corporate identity PLN. Responden tidak mengingat dengan benar logo perusahaan, dan hal yang pertama diingat ketika mengingat PLTMH bukanlah PLN namun justru kondisi listrik di Lebak Picung yang sempat mati selama berbulan-bulan. Terdapat 43 responden ( 83 persen) dengan skor total antara 8-12 menilai PLN dengan corporate identity yang cukup baik, responden menilai PLN sebagai perusahaan yang mudah diingat karena memiliki keunikan yang khas dan berbeda dengan perusahaan lainnya. 
Tabel 14. Jumlah dan Presentases Responden Berdasarkan Penlaian Terhadap Copporate Identiby Perusahaan

\begin{tabular}{clcc}
\hline No. & Penilaian Terhadap Corporate Identity Perusahaan & \multicolumn{2}{c}{ Jumlah } \\
\cline { 3 - 4 } & & J & Persen \\
\hline 1 & Kurang baik $(\leq 1)$ & 1 & 2 \\
2 & Cukup baik $(8-12)$ & 43 & 83 \\
3 & Sangat baik $(213)$ & 8 & 15 \\
\hline \multicolumn{2}{c}{ Jumlah } & 52 & 100 \\
\hline
\end{tabular}

Delapan responden (15 persen) lainnya menilai corporate identity perusahaan dengan sangat baik, responden mengungkapkan bahwa PLN merupakan perusahaan dengan logo yang mudah diingat, sampai menjadi perusahaan yang identik dengan PLTMH, serta perusahaan yang mudah diingat karena sangat berbeda dengan perusahaan lainnya.

\section{Penilaian Terhadap Citra Perusahaan}

Citra PLN dilihat melalui keseluruhan penilaian responden pada corporate identity, personality, reputation, serta value ethic perusahaan. Berdasarkan Tabel 15, terdapat tujuh belas responden (33 persen) yang lain menilai PLN sebagai perusahaan dengan citra yang sangat baik. PLN telah memliki personality sebagai perusahaan dengan tanggungjawab sosial yang tinggi, serta perusahaan yang dapat dipercaya. Pengalaman secara langsung sebagai sasaran program PLTMH, membuat responden memiliki reputation yang baik karena telah menjadi perusahaan dengan tingkat kepedulian yang tinggi terhadap kebutuhan listrik masyarakat walau yang berada di daerah yang sulit dijangkau. Responden menilai PLN sebagai perusahaan dengan value ethic yang baik karena selain memberikan manfaat dan kegiatan yang dijalankan perusahaan telah sesuai dengan nilai dan norma di masyarakat dan PLN juga memiliki corporate identity yang khas dan mudah diingat.

Tabel 15.Jumlah dan Presentase Responden Berdasarkan Peenlaian Terhadap Citra Perusahhann Listrik Negegara

\begin{tabular}{|c|c|c|c|}
\hline \multirow[t]{2}{*}{$\mathrm{N}_{0}$} & \multirow{2}{*}{ Penilaian Terhadap Citra PLS } & \multicolumn{2}{|c|}{ Jumlah } \\
\hline & & I & Persen \\
\hline 1 & Kurang baik $(\leq 11)$ & 0 & 0 \\
\hline 2 & Cukup balk (12-18) & 35 & 67 \\
\hline 3 & Sangat baik (218) & 17 & 33 \\
\hline & Jumlah & 52 & 100 \\
\hline
\end{tabular}

Sebagian besar responden yaitu 35 orang (67 persen) memiliki skor 12-18 yang berarti menilai PLN dengan citra yang cukup baik. responden menilai PLN dengan personality, reputation, value ethic, dan corporate identity yang sedang, tidak terlalu baik namun juga tidak terlalu buruk.

Responden menilai PLN dengan personality sebagai perusahaan yang memiliki tanggung jawab pada kesejahteraan masyarakat namun sebagian responden menyatakan bahwa PLN belum bisa dikatakan sebagai perusahaan yang dapat dipercaya dan belum sepenuhnya melakukan langkah kongkrit untuk memberdayakan masyarakat karena tidak pernah ada kunjungan yang dilakukan perusahaan ke tempat mereka. Cara PLN yang sebenarnya mendorong masyarakat untuk mandiri mengelola PLTMH dinilai lain oleh responden. Reputation PLN pada responden sudah baik, namun responden belum sepenuhnya setuju bahwa PLN konsisten memberdayakan masyarakt dan berupaya mencari tahu kebutuhan masyarakat, hal ini didasarkan oleh pengalaman mereka selama PLTMH mengalami kematian dan penggantian mesin yang sepenuhnya menjadi tanggungjawab masyarakat. Responden menilai PLN sebagai perusahaan dengan value ethic yang baik, namun penilaian terhadap corporate identity kurang baik.

\section{PENGARUH COMMUNITY RELATIONS PROGRAM PLTMH PADA PEMBENTUKAN CITRA PERUSAHAAN LISTRIK NEGARA (PLN)}

\section{Analisis Hubungan Pelaksanaan Program PLTMH dengan Proses Pembentukan Citra}

Pelaksanaan program PLTMH dilihat berdasarkan keterlibatan sasaran program dan penilaian sasaran program terhadap manfaat PLTMH. Proses pembentukan citra dinilai dari tingkat penangkapan informasi, tingkat perhatian, serta tingkat pemahaman. Berdasarkan uji korelasi dengan menggunakan rank spearman corellation diperoleh nilai Asymp. Sig. (2-tailed) hitung sebesar $0,000<\alpha(0,10)$ sehingga $\mathrm{H}_{1}$ diterima dan $\mathrm{H}_{0}$ ditolak. Ini menunjukkan bahwa terdapat hubungan nyata antara pelaksanaan community relations melalui program PLTMH dengan proses pembentukan citra pada sasaran program. Program PLTMH yang sesuai dengan kebutuhan sasaran program membuat masyarakat mudah menyerap informasi terkait PLTMH dan perusahaan, memliki ketertarikan untuk mengetahui program dan perusahaan lebih lanjut, dan memiliki penerimaan yang tinggi terhadap program dan perusahaan.

Tabel 16. Hubungan Pelaksanaan Program PLTMH dengan Proses Pembentukan Citra

\begin{tabular}{|c|c|c|c|c|}
\hline & & \multicolumn{2}{|c|}{ Proses Pembentukan Citra } & \multirow{2}{*}{ Total } \\
\hline & & Cukup Baik & Sangat Baik & \\
\hline \multirow{4}{*}{ Pelaksanaan Program } & Cukun Baik & 25 & 2 & 27 \\
\hline & & (92.6 persen) & (7.4persen) & (100.0persen) \\
\hline & Sangat Baik & 10 & 15 & 25 \\
\hline & Sangal Dalk & (40.0persen) & (60.0persen) & (100.0persen) \\
\hline \multirow{2}{*}{\multicolumn{2}{|c|}{ Total }} & 35 & 17 & 52 \\
\hline & & (67.3 persen) & (32.7persen) & (100.0persen) \\
\hline
\end{tabular}

Tabel 16 memperlihatkan bahwa dua puluh tujuh responden yang memiliki penilaian bahwa pelaksanaan program PLTMH sudah cukup baik cenderung memiliki proses pembentukan citra yang cukup baik juga yaitu sebanyak 25 responden (92,6 persen), dan dua responden lain $(7,4$ persen) dengan proses pembentukan citra tinggi. Responden dengan proses pembentukan citra yang sangat baik juga cenderung memiliki proses pembentukan citra yang sangat baik juga. Dua puluh lima responden $(100,0$ persen) yang menilai bahwa program PLTMH telah dilaksanakan dengan sangat baik, sebanyak lima belas responden (60 persen) memiliki proses pembentukan citra yang sangat baik dan sepuluh responden (40 persen) dengan proses pembentukan citra yang cukup baik. Hubungan antara pelaksanaan program PLTMH dengan proses pembentukan citra dilihat melalui hubungan keterlibatan responden dalam program dengan tingkat penangkapan informasi (exposure), hubungan keterlibatan 
responden dalam program dengan tingkat perhatian (attention), serta hubungan penilaian responden terhadap manfaat program dengan tingkat pemahaman (comprehensive).

Berdasarkan uji korelasi, tidak menunjukkan adanya hubungan antara keterlibatan sasaran program dalam program dengan tingkat penangkapan informasi (exposure). Tingkat penangkapan informasi justru memiliki hubungan dengan penilaian sasaran program terhadap manfaat program. Manfaat program juga memiliki hubungan positif dengan tingkat perhatian (attention). Sehingga program yang memberikan manfaat yang sesuai dengan kebutuhan sasaran program, akan membuat sasaran program cenderung memiliki informasi tentang program maupun perusahaan, melalui informasi yang dimiliki maka untuk mampu menilai citra maka akan melalui tahap perhatian. Responden yang makin menyadari bahwa program mampu memberikan manfaat positif bagi sasaran program maka akan memiliki tingkat perhatiannya akan semakin tinggi. Sasaran program memiliki perhatian dengan mencari tahu lebih lanjut tentang program serta perusahaan. Setelah tahap perhatian, sasaran program akan melalui tahap pemahaman. Berdasarkan data yang didapatkan, tingkat pemahaman juga berhubungan dengan penilaian sasaran program terhadap manfaat program. Sedangkan keterlibatan dalam program yang di duga memiliki hubungan dengan tingkat penangkapan informasi (exposure) serta tingkat perhatian (attention) ternyata tidak terbukti berhubungan.

\section{Analisis Hubungan Proses Pembentukan Citra dengan Citra Perusahaan yang Terbentuk}

Proses pembentukan citra perusahaan dalam penelitian ini dilihat berdasarkan tingkat penangkapan informasi, tingkat perhatian, serta tingkat pemahaman sasaran program. Sedangkan citra perusahaan dilihat berdasarkan penilaian responden terhadap personality, reputation, value ethic, serta corporate identity pemberi program yang dalam kasus ini merupakan PLN.

Uji korelasi dengan menggunakan rank spearman menunjukkan nilai Asymp. Sig. (2-tailed) hitung sebesar $0,000<\alpha(0,01)$. Hasil uji korelasi ini menunjukkan signifikansi hubungan antara proses pembentukan citra dengan citra perusahaan yang terbentuk. Hubungan positif antara kedua variabel menunjukkan bahwa semakin baik proses pembentukan citra pada sasaran program yaitu semakin tinggi tingkat penangkapan informasi, tingkat perhatian, serta tingkat pemahaman maka citra perusahaan yang terbentuk pun semakin positif.
Tabel 17. Hubungan Proses Pembentukan Citra dengan Citra Perusahaan

\begin{tabular}{rrrrr}
\hline & & \multicolumn{2}{c}{ Citra Perusahaan } & \multirow{2}{*}{ Total } \\
\cline { 3 - 4 } & & Cukup Baik & Sangat Baik & \\
\hline \multirow{2}{*}{$\begin{array}{c}\text { Proses Pembentukan } \\
\text { Citra }\end{array}$} & Cukup Baik & 29 & 6 & 35 \\
& & $(82.9$ persen $)$ & $(17.1$ persen $)$ & $(100.0$ persen $)$ \\
& Sangat Baik & 6 & 11 & 17 \\
& & $(35.3$ persen $)$ & $(64.7$ persen $)$ & $(100.0$ persen $)$ \\
\hline \multicolumn{2}{c}{ Total } & $(67.3$ persen $)$ & $(32.7$ persen $)$ & $(100.0$ persen $)$ \\
\hline
\end{tabular}

Data pada Tabel 17 menunjukkan bahwa responden yang memiliki proses pembentukan citra yang cukup baik yaitu sebanyak 35 responden (100,0 persen), dan 29 responden (82,9 persen) diantaranya cenderung menilai perusahaan dengan citra yang cukup baik, dan yang lain (17,1 persen) menilai PLN dengan citra sangat baik. Sedangkan responden dengan proses pembentukan citra perusahaan yang baik cenderung menilai perusahaan dengan citra yang sangat baik, yaitu dari tujuh belas responden $(100,0$ persen) dengan proses pembentukan citra perusahaan baik, sebanyak sebelas responden ( 64,7 persen) menilai PLN sebagai perusahaan dengan citra yang sangat baik.

Pada penelitian ini, sebagian besar responden yaitu sebanyak 67,3 persen memiliki proses pembentukan citra yang sedang atau cukup baik, ini berdasarkan tingkat penangkapan informasi sebagian besar responden yang memang sedang, dimana responden tidak mengetahui tentang prosuder penggantian alat jika mengalami kerusakan. Warga Lebak Picung hanya mengetahui satu nama orang PLN dari PLN-JP Bandung dan tidak ada yang mengenal nama dari PR PLN. Hal ini membuat kerusakan yang pernah terjadi pada mesin PLTMH, membuat perwakilan warga pergi ke Bandung tanpa mengetahui prosuder ataupun informasi lebih lanjut selain nama salah satu pegawai PLN, dan tak membuahkan hasil. Ini menjadi salah satu penyebab personality dari citra PLN tidak sepenuhnya baik, terdapat responden yang menilai PLN belum menjadi perusahaan yang dapat dipercaya karena penggantian alat yang semula dalam perjanjian menjadi tanggung jawab PLN namun karena ketidaktahuan prosedur yang harus dilakukan sasaran program menyebabkan merea harus membeli sendiri alat tersrbut.

Berkaitan dengan pengalaman PLTMH yang sempat mengalami kematian saat musim kemarau karena debit air sungai yang sedikit menyebabkan sasaran program memiliki tingkat afektif dalam tingkat perhatian yang sedang juga. Sasaran program belum sepenuhnya merasa bahwa program PLTMH yang dilakukan PLN mampu memenuhi kebutuhan listrik di Lebak Picung. Tingkat perhatian yang sedang menyebabkan responden menilai citra PLN dengan personality yang belum sepenuhnya baik karena kinerja yang ditunjukkan belum bagus. Sebenarnya pelaksanaan PLTMH sepenuhnya diserahkan perusahaan kepada masyarakat untuk mandiri memelihara dan menjaga keberlangsungan PLTMH. PLTMH tergantung pada potensi yang ada disana, yaitu aliran sungai Ciambulawung. Tidak adanya hujan dan adanya sampah di aliran sungai menjadi salah satu penyebab matinya PLTMH, sebagian warga mengetahui sepenuhnya bahwa PLTMH tergantung dengan debit air 
sungai sehingga mereka menjaga agar tidak menebang pohon sembarangan dan tidak membuang sampah ke sungai, namun sebagian responden tetap menganggap kematian itu disebabkan oleh ketidakadaannya pihak PLN yang mengontrol secara rutin ke lokasi mereka. PLTMH sebenarnya dilakukan PLN dengan konsep mandiri energi, yaitu masyarakat sebagai sasaran program mampu memanfaatkan potensi yang ada di daerah mereka, menjaga dan mengelola secara mandiri sehingga PLN tidak melakukan pengontrolan rutin karena daerah sasaran program CSR PLN menyebar di seluruh Indonesia. Namun ini diartikan lain oleh masyarakat, dan membuat penilaian terhadap citra perusahaan tidak sepenuhnya baik.

Dampak positif dari PLTMH yang dirasakan langsung oleh sasaran program menyebabkan sebagian responden memiliki tingkat perhatian yang tinggi. Tingkat perhatian tinggi responden menyebabkan mereka menilai citra PLN dengan reputation yang baik, sebagai perusahaan yang tidak hanya mengejar keuntungan semata namun peduli dengan kesejahteraan masyarakat dan telah menjadi perusahaan yang peduli dengan kebutuhan listrik masyarakat walaupun berada di daerah yang sulit dijangkau seperti lokasi mereka tinggal.

Responden memiliki tingkat pemahaman yang tinggi karena memiliki kesediaan menjaga keberlangsungan PLTMH, penerimaan yang tinggi terhadap PLN untuk melakukan kegiatan atau program lain di sekitar lokasi mereka tinggal, namun responden keberatan menjadi pengurus atau pengelola. Hal ini mempengaruhi penilaian responden terhadap citra perusahaan.

Secara garis besar citra perusahaan yang terbentuk pada sasaran program community relations melalui PLTMH sudah cukup baik, sebanyak 35 responden (67,3 persen) menilai PLN dengan citra yang sedang yaitu tidak terlalu baik namun tidak juga buruk, tujuh belas responden lain (33,7 persen) menilai PLN dengan citra yang sangat baik, dan tidak terdapat responden yang menilai PLN dengan citra yang buruk. Program Community Relations melalui PLTMH yang memiliki manfaat positif bagi sasaran program berpengaruh pada tingginya proses pembentukan citra, proses pembentukan citra yang baik mempengaruhi penilaian responden terhadap citra PLN dengan baik juga.

\section{PENUTUP}

\section{Kesimpulan}

Community relations melalui program PLTMH di Lebak Picung dilaksanakan PLN dengan menekankan kemandirian pada masyarakat untuk memanfaatkan potensi sungai Ciambulawung sebagai sumber listrik bagi seluruh rumah tangga di Lebak Picung. Pemanfaatan dan pengelolaan sepenuhnya diserahkan pada masyarakat, tidak ada pengontrolan rutin PLN ke salah satu lokasi saja seperti ke Lebak Picung karena lokasi sasaran program CSR PLN tersebar di seluruh nusantara. Sayangnya komunikasi antara sasaran program dengan perusahaan masing belum efektif sehingga tidak semua informasi dimiliki oleh sasaran program.

Penilaian terhadap pelaksanaan PLTMH dilihat dari keterlibatan sasaran program dalam program dan manfaat program yang dirasakan. Keterlibatan dalam program tidak memperlihatkan adanya hubungan dengan proses pembentukan citra, hal ini dimungkinkan karena keterlibatan sasaran program hanya dilihat berdasarkan kehadiran dalam perencanaan, pembangunan, hingga pengelolaan bukan pada partisipasi yang dilakukan. Manfaat program memiliki hubungan dengan proses pembentukan citra, karena mempengaruhi tingkat penangkapan informasi, tingkat perhatian, dan tingkat pemahaman sasaran program. Program PLTMH dinilai responden telah mampu memenuhi kebutuhan listrik masyarakat di Lebak Picung sehingga proses pembentukan citra pada responden cukup baik dan sangat baik.

Proses pembentukan citra pada sasaran program secara signifikan mempengaruhi citra perusahaan yang terbentuk pada sasaran program. Proses pembentukan citra yang cukup baik dan baik menyebabkan sebagian besar responden menilai reputation, personality, corporate identity, dan value ethic PLN dengan citra yang cukup baik. Secara keseluruhan PLN telah menjadi perusahaan yang peduli dengan kebutuhan listrik di masyarakat yang ditunjukkan dengan kemampuannya menjangkau daerah terpencil seperti lokasi mereka. Community relations yang dilakukan melalui program community empowering PLTMH di Lebak Picung telah mampu meningkatkan citra PLN pada sasaran program.

\section{Saran}

1. Perusahaan yang menjalankan program pemberdayaan, harus memperhatikan bahwa program yang dijalankan sesuai dengan kebutuhan sasaran program.

2. Program pemberdayaan bisa menjadi program yang menguntungkan bagi perusahaan jika dilakukan dengan pendampingan dengan tepat. Kemandirian sasaran program harus benar-benar diperhatikan agar program pemberdayaan yang dilakukan bisa menjadi kerjasama strategis antara kedua belah pihak.

3. Komunikasi antar pihak yang melakukan relasi harus diperhatikan dengan baik. Informasi yang dimiliki perusahaan harus disampaikan ke pihak yang lain agar tidak terjadi salah penafsiran antar pihak.

4. Perlu dilakukan jadwal pengontrolan terhadap pelaksanaan program, setidaknya sekali dalam setahun sebagai bentuk komunikasi dan peningkatan hubungan antara perusahaan dengan masyarakat sekaligus sebagai upaya langsung perusahaan untuk menghimpun masukan dari sasaran program dan pemeliharaan citra.

\section{DAFTAR PUSTAKA}

Cutlip M. Scoot, Center Allan H, Broom Glen M. 2000. Effective Public Relations, 6th edition. New Jersey: Prentice-Hall, Inc.

Effendy Onong Uchjana. 2002. Hubungan Masyarakat Suatu Studi Komunikologis. Bandung: Remaja Rosdakarya. 
Effendy Onong Uchjana. 1993. Human Relations dan Public Relations. Bandung: Mandar Maju.

Gregory Anne. 2001. Perencanaan dan Manajemen Kampanye Public Relations edisi Kedua. Jakarta: Erlangga.

Handini Meutia Esti. 2010. Analisis Perubahan Penutupan dan Pola Pemanfaatan Lahan di Taman Nasional Gunung Halimun Salak Menggunakan Sistem Informasi Geografi (Studi Kasus: Kampung Adat Lebak Picung). Skripsi. Bobogr: Institut Pertanian Bogor.

Harrison Shirley. 1995. Marketers Guide To Public Relations. New York: John Willy and Son.

Hawkins Del I., Roger J. Best, Kenneth A. Coney. 1996. Consumer Behavior: Building Marketing Strategy. USA: McGraw-Hill

Iriantara Yosal. 2007. Community Relations Konsep dan Aplikasinya. Bandung: Simbiosa Rekatama Media.

Jefkins Frank. 1992. Public Relations Edisi Keempat. Jakarta: Erlangga.

Khasali Renald. 1994. Manajemen Publis Relations: Konsep dam Aplikasinya di Indonesia. Jakarta: Pustaka Utama

Kotler Philip. 2000. Marketing Management (The Mellenium Edition). New Jersey: Prentice-Hall, Inc. Upper Saddle River.

Nazir M. 2005. Metode Penelitian. Bogor: Ghalia Indonesia.

Novianti Noval.2010. Strategi Public Relations dalam Mempertahankan Eksistensi Corporate Image melalui Opini Publik (Studi Kasus PT Indocement Tunggal Prakarsa Tbk). Skripsi. Bogor: Departemen Sains Komunikasi dan Pengembangan Masyarakat Fakultas Ekologi Manusia Institut Pertanian Bogor.

Purwanto Y. Aris, Lilik B. Prasetya, Ellyn K. Damayanti, Rais sonaji. 2009. Model Desa Mandiri Energi Berbasis Mikrohidro di Sekitar Taman Nasional. Bogor: Institut Pertanian Bogor

Rumanti Masria Asumpta. 2002. Dasar-Dasar Public Relations Teori dan Praktik. Jakarta: Grasindo.

Ruslan Rosady. 1998. Manajemen Humas \& Manajemen Komunikasi (Konsepsi \& Aplikasinya). Jakarta: Raja Grafindo Persada.

Ruslan Rosady. 2003. Metode Penelitian Public Relations dan Komunikasi. Jakarta: Raja Grafindo Persada.

Sarwono Jonathan. 2006. Metode Penelitian Kuantitatif \& Kualitatif. Bandung: Graha Ilmu. 286 Hal.

Singarimbun Masri, Sofian Effendi. 1989. Metode Penelitian Survai. Jakarta: LP3ES.

Suwandi Iman Mulyana Dwi. 2007. Citra Perusahaan Seri Manajemen Pemasaran. (http://oeconomicus.filrs.wordPress.com/2007/citr a-perusahaan.pdf). [diakses 17 Mei 2011]
Trihendradi Cornelius. 2010. Step by Step SPSS 18 Analisis Data Statistik. Yogyakarta: Penerbit Andi. 